\title{
Environmental Externalities: Applying the Concept to Asian Coal-Based Power Generation
}

by C.B. Szpunar and J.L. Gillette

Environmental Assessment and Information Sciences Division, Argonne National Laboratory, 9700 South Cass Avenue, Argonne, Illinois 60439

September 1992 (printed March 1993)

Work sponsored in part by U.S. Agency for International Development, 


\section{CONTENTS}

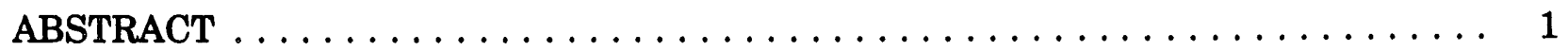

1 INTRODUC'TION $\ldots \ldots \ldots \ldots \ldots \ldots \ldots \ldots \ldots \ldots \ldots \ldots \ldots \ldots \ldots$

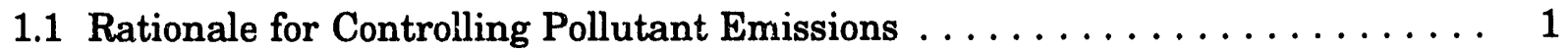

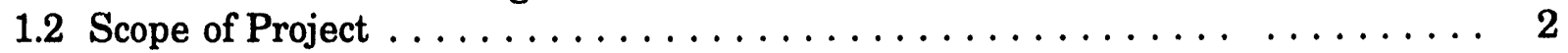

2 EXTERNALITIES $\ldots \ldots \ldots \ldots \ldots \ldots \ldots \ldots \ldots \ldots \ldots \ldots \ldots$

2.1 Definition of Externality $\ldots \ldots \ldots \ldots \ldots \ldots \ldots \ldots \ldots \ldots \ldots \ldots \ldots$

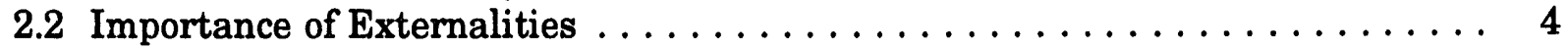

2.3 Components of Externality Valuation $\ldots \ldots \ldots \ldots \ldots \ldots$

3 THEORETICAL APPROACH TO THE VALUATION

OF ENVIRONMENTAL EXTERNALITIES $\ldots \ldots \ldots \ldots \ldots \ldots \ldots$

3.1 General Relationships to Be Considered $\ldots \ldots \ldots \ldots \ldots \ldots \ldots \ldots$

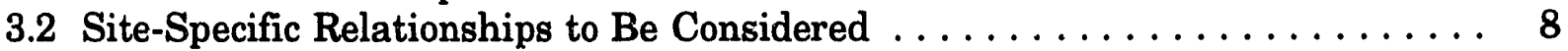

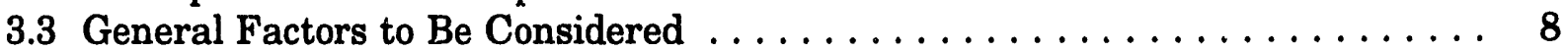

3.3.1 Factors Related to Risk and Value of Life $\ldots \ldots \ldots \ldots \ldots \ldots$

3.3.2 Factors Related to Valuation of Risk . . . . . . . . . . . . . 9

3.3.3 Factors Related to the Specific Cost of Abatement . . . . . . . . . . . 10

4 RESEARCH CONTRIBUTING TO THE UNDERSTANDING

OF ENVIRONMENTAL EXTERNALITIES $\ldots \ldots \ldots \ldots \ldots \ldots \ldots \ldots$

4.1 Research on Air Pollutants that Affect Human Health . . . . . . . . . 12

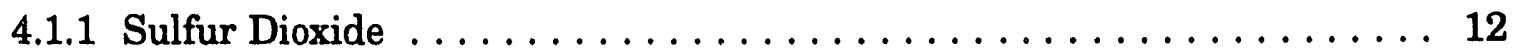

4.1 .2 Particulates . . . . . . . . . . . . . . . . . . . 13

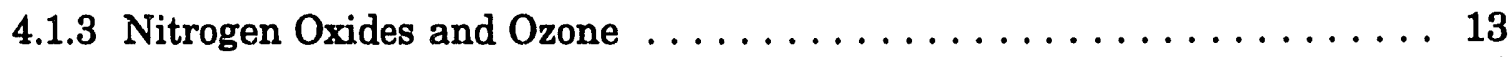

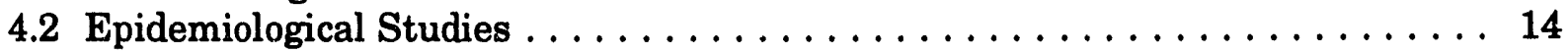

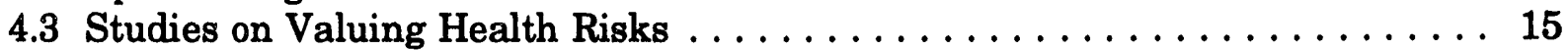

4.4 Studies on Monetizing Environmental Externalities $\ldots \ldots \ldots \ldots \ldots \ldots \ldots$

4.5 Study on Eliminating or Improving the Environmental

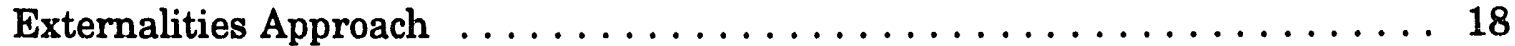

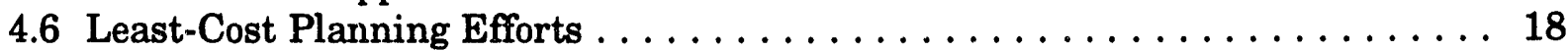

5 SIMPLIFIED /APPROACH FOR VALUATION

OF ENVIRONMENTAL EXTERNALITIES $\ldots \ldots \ldots \ldots \ldots \ldots \ldots$

5.1 Measuring Asian Air Quality Conditions $\ldots \ldots \ldots \ldots \ldots \ldots \ldots \ldots$

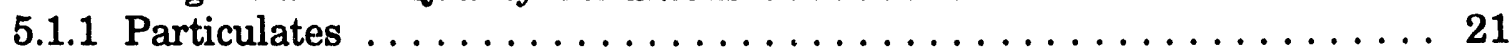

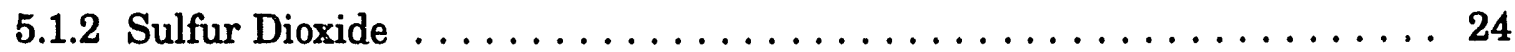

5.1 .3 Ozone . . . . . . . . . . . . . . . . . . . . . 25

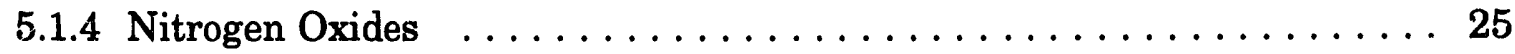




\section{CONTENTS (Cont.)}

5.2 Determining Environmental Externality Values

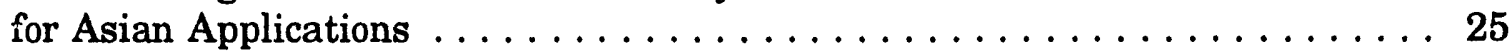

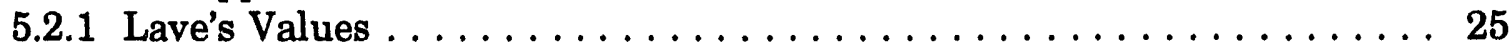

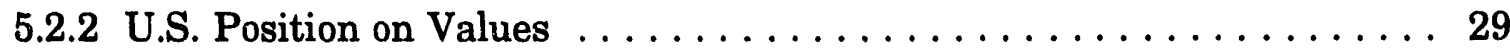

5.2.3 Application of Lave's Values to Asian Situation . . . . . . . . . . 29

6 APPLYING ENVIRONMENTAL EXTERNALITIES

TO ASIAN COUNTRIES $\ldots \ldots \ldots \ldots \ldots \ldots \ldots \ldots \ldots \ldots \ldots \ldots \ldots$

6.1 Scenario Assumptions $\ldots \ldots \ldots \ldots \ldots \ldots \ldots \ldots \ldots \ldots \ldots \ldots \ldots \ldots$

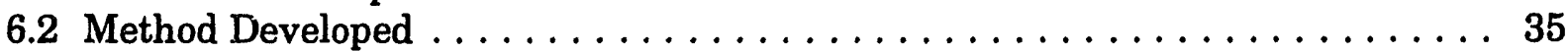

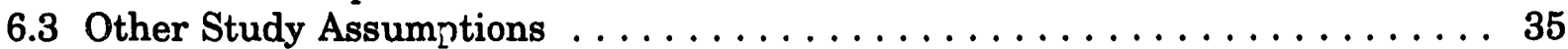

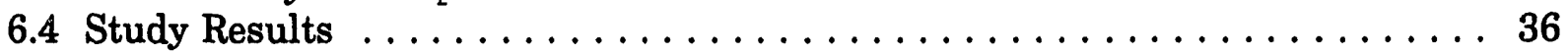

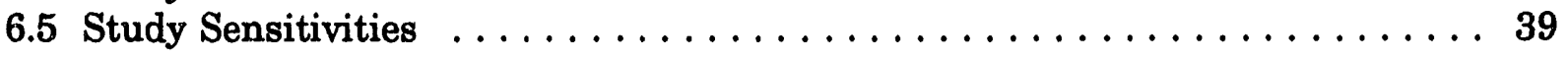

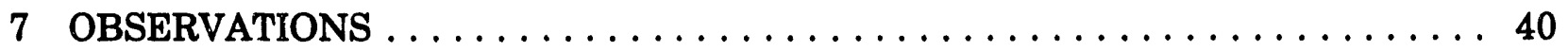

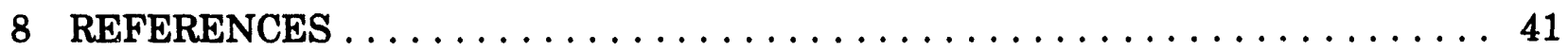

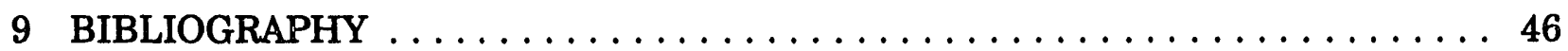

\section{TABLES}

1 Research on Valuing Health Risks from Electricity Generation $\ldots . \ldots \ldots \ldots 16$

2 Annual Average Ambient Levels of Particulates . . . . . . . . . . . . . 22

3 Annual Average Ambient Levels of Sulfur Dioxide $\ldots \ldots \ldots \ldots \ldots \ldots \ldots$

4 Sample Values Used by State Public Utilities and Others for

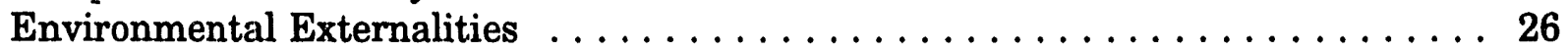

5 Base-Case Emission Rates and Reduction Levels, by Technology . . . . . . . . . . 32

6 Representative Coal Quality Characteristice for Indonesia and Thailand ...... 33

7 Representative Coal Quality Characteristics for Taiwan .............. 34

8 Ratio of Reduced Cost of Environmental Externalities to Increased Cost of Electricity Production in Indonesia and Thailand . . . . . . . . . . . 37

9 Ratio of Reduced Cost of Environmental Externalities to Increased Cost of Electricity Production in Taiwan $\ldots \ldots \ldots \ldots \ldots \ldots \ldots \ldots \ldots \ldots$ 


\section{FIGURES}

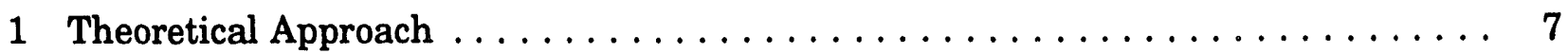

2 Simplified Approach Derived from a Theoretical Approach ............. 20 


\title{
ENVIRONMENTAL EXTERNALITIES: APPLYING THE CONCEPT TO ASIAN COAL-BASED POWER GENERATION
}

by

\author{
C.B. Szpunar and J.L. Gillette
}

\begin{abstract}
This report examines the concept of environmental externality. It discusses various factors - the atmospheric transformations, relationship of point-source emissions to ambient air quality, dose-response relationships, applicable cause-and-effect principles, and risk and valuation research - that are considered by a number of state utilities when they apply the environmental externality concept to energy resource planning. It describes a methodology developed by Argonne National Laboratory for general use in resource planning, in combination with traditional methods that consider the cost of electricity production. Finally, it shows how the methodology can be applied in Indonesia, Thailand, and Taiwan to potential coal-fired power plant projects that will make use of clean coal technologies.
\end{abstract}

\section{INTRODUCTION}

Coal is an abundant resource found in many locations throughout the world. It is, and has been for many years, one of the most widely used sources of energy for the various activities and processes that are a part of everyday life, including cooking, heating, transportation, industrial processes, and the production of electricity. Its use in the industrial and electric utility sectors is expected to grow as these sectors attempt to reduce their dependence on imported oil. Increased use of coal is anticipated to occur not only in industrialized countries, where demand for electricity and industrial products is growing steadily, but also in developing and newly industrializing countries, where opportunities to expand industrial production and provide electricity in a rapidly expanding society abound.

\subsection{RATIONALE FOR CONTROLLING POLLUTANT EMISSIONS}

Significant benefits to human health that result from emissions control programs may justify the costs of pollution control policies. In fact, many scientists, economists, risk analysts, and policymakers believe that comparisons of the benefits (as measured in monetary value) and the costs of pollution control demonstrate that the U.S. program for controlling airborne emissions from stationary sources, including coal-fired power-generating units), is justified (Freeman 1982). This U.S. program is justified on the basis that it results 
in pronounced benefits to human health, most of which are achieved from the control of emissions of suspended particulates and sulfur compounds.

Utilities usually base their market decisions on a consideration of traditional costs, such as capital, operating and maintenance (O\&M), and fuel costs. A consideration of social costs - which could be significant - is usually not explicitly incorporated into such decisions. These social costs could result in a net reduction in the welfare of individuals and of society as a whole. However, because these social costs and their effects are not represented in the price of energy, decision makers have no way to explicitly value them, and they remain unaccounted for in market decisions (Finnell et al. 1990). If these external costs were accounted for when energy sources were being selected and energy products were being derived, the process could lead to a state of equilibrium, in which maximum benefits would be realized; that is, the total cost of energy and energy products, together with the resulting social costs, would be at its economic minimum.

A program for controlling air emissions would be of interest to the ASEAN countries (Brunei, Indonesia, Malaysia, the Philippines, Singapore, and Thailand) and their governments and to other Asian countries, especially if such a program could be justified in cost-benefit terms and shown to be directly applicable to Asian conditions. Although a comparison of costs and benefits might not be fair, Asian policymakers would surely be encouraged to consider more stringent policies and guidelines to better protect the health and welfare of the people they serve if such a comparison were to reveal that the benefits to human health and to various aspects of the environment (agriculture, materials, visibility, etc.) outweighed the costs (even if they were only the costs of the basic control technology). It is the intent of the effort described herein to demonstrate that technical options are available to control emissions from coal-based, electric power plants and that the costs of these options can, in fact, be justified in cost-benefit terms.

\subsection{SCOPE OF PROJECT}

All energy conversion technologies pose some risk to society. Economists and social scientists continue to develop monetary values to represent loss of life, illness, global warming, decreased visibility, acid rain, and other consequences of generally beneficial electricity production. These monetary values have been translated to emissions through consideration of dose-response relationships ${ }^{1}$ and similar cause-and-effect principles.

As a result of increased public pressure and evolving regional, national, and international regulatory requirements, electric utility authorities around the globe are

1 According to Lave and Seskin (1977, pp. 16-17): "The term dose-response relationship refers to the proportion of a given population that exhibits a specified response as a function of the dose (or concentration) of the toxic substance. Typically, a dose-response curve will exhibit a cumulative normal or $\mathbb{S}$ shape, since some individuals will be relatively sensitive to the substance (and thus exhibit the response at low concentrations), while other individuals will be relatively insensitive (and thus not exhibit the response until the concentrations are quite high)." 
becoming more cognizant of environmental issues associated with electric power production. However, the concerns related to environmental issues seem to be limited to ensuring regulatory compliance and incorporating the resultant additional costs into the cost of electricity. Few evaluations of the long-range impacts or future consequences of the emissions or residuals are conducted. In addition, the values for externalities (i.e., social costs) that have been used to date as a basis for evaluating and comparing various options pose tremendous uncertainty and need to be explained, discussed, and considered.

The work represented in this report was undertaken to illustrate, through examples, how the costs and benefits of controlling emissions - specifically those from new, advancedtechnology, coal-based, electricity-generating power plants in Asia - might be considered in utility market decisions. Although the basic methodology developed for this effort can be applied in general, the specific examples discussed herein apply to Indonesia, Thailand, and Taiwan and their use of indigenous and imported coals. Nevertheless, as new technologies designed to be more environmentally benign than current ones begin to enter the commercial marketplace, the simple yet quantitative techniques developed for this project will be available to be utilized in comparing the various options.

More importantly, the work represented here could easily be extended and used in studies of coal-based retrofit applications and comparisons of other fuels. Because the initially commissioned project scope did not permit consideration of these topics, however, they are not addressed here.

This report covers emissions to the atmosphere from the power-generating phase of the fuel cycle. It does not address emissions, discharges, or pollutants other than those dispersed by air (i.e., it does not cover waterborne emissions or those related to land use). In addition, it does not consider the whole fuel cycle - mining, transportation, power generation, waste disposal, etc. It compares coal-based technologies; it does not consider some factors that might be important in comparisons of technologies that use fuels other than coal. 


\section{EXTERNALITIES}

\subsection{DEFINITION OF EXTERNALITY}

The term externality may be defined in a number of ways. Recent examples are:

- A societal cost or benefit that is not reflected in the price of an activity and not limited to the environment, but that should be of concern to the decision maker when choosing how much to pollute, how to control emissions, and what to charge for products (Joskow 1991).

- A benefit or cost borne by individuals who are not responsible for making a specific decision; in other words, a benefit involuntarily received by people who did not pay for it or a cost imposed on people who did not get any compensation for it (Easterling et al. 1990).

- A reference to the damage to the environment that occurs as an unintended by-product of the production or use of electricity (Jones and Hanser 1991).

- An external or social cost related to any unpriced impacts created in the process of energy production and use, typically in the form of environmental damage, adverse health effects, and materials damage (Finnell et al. 1990).

\subsection{IMPORTANCE OF EXTERNALITIES}

Historically, the market price of conventional energy forms has not fully accounted for all the resultant external costs imposed on society. Emissions trading, taxes, other pricing modes, or combinations thereof would internalize some of the cost, thereby reducing the cost of an externality. In practice, however, electricity-generating bodies do not usually take into account the magnitude of costs imposed on society when they price electricity. Nevertheless, externalities (i.e., social costs or social benefits) are rapidly becoming priorities in electricity-generation considerations for the following reasons:

- Economic growth and a concomitant exparsion in electricity demand and related environmental impacts make social costs more widespread.

- A greater scientific understanding of external impacts makes estimates meaningful and more accurate.

- Improved valuation methods make the actual costs of these external impacts easier to estimate and more accurate. 
- The emergence of institutional mechanisms (e.g., least-cost planning and competitive bidding) makes consideration of social costs and benefits possible and necessary.

- A much broader range of technological choices is becoming available to utilities (at varying costs) to mitigate many externalities.

\subsection{COMPONENTS OF EXTERNALITY VALUATION}

To value externality costs, or "internalize" them into the decision process, (1) impacts must be identified and quantified and (2) values for these impacts must be developed. Attempting to fully describe the entire range of effects in electricity-generating processes is difficult in itself. Placing a value on each individual effect, moreover, is considerably more difficult, particularly because these costs fall outside the normal market pricing system; that is, real information on market costs is usually not available (Boras et al. 1990).

In considering and applying externality costs, the first step is to identify and quantify the necessary dose-response and physical damage functions ${ }^{2}$ involved. The second step is to discuss, accept, and gain consensus, if possible, on the validity of the economic value of statistical lives ${ }^{3}$ (a very controversial concept). The third step is to apply the appropriate economic data in deliberations, even though, in general, these data are costly and difficult to gather. The fourth step is to recognize that, even with the appropriate data, significant uncertainty and imprecision in the estimates will continue to exist (Freeman 1982).

Accurately attributing costs to their sources is not yet a finely developed science, and this situation may influence which parameters are selected. Values have been applied to:

- The costs of environmental damage (i.e., the costs of the damages inflicted on society by pollutants) and

- The costs of technology control (i.e., the costs of controlling or mitigating pollution damages).

2 According to Ottinger et al. (1990): "A mathematical relationship expressing an estimate of the number and kind of physical effects resulting from exposure to some quantity of a substance; typically expressed as the number oi deaths (or some other response) resulting from an annual exposure to some pollutant (typically given in micrograms per cubic meter per year)."

3 According to Ottinger et al. (1990), Daly (1990) provides the following description: "The economic value of environmental risks can be based either on the costs of avoiding the risk, the 'control costs,' or the costs of the damage imposed on society by the risk, the 'damage costs.' [Because the] risk to life (i.e., a statistical life) must be given a dollar value does not mean that loss of (an individual) life is treated as a strictly economic commodity. [There is an] inadequacy of current macroeconomic theory to analyze risks to human life and the environment, and the need for a new vision of ecological economics. ..." 
Moreover, the specific definitions that are used and assumptions that are made introduce significant complexity into the calculation of externality costs, and certain costs are traded off against other costs, thus affecting which impacts are mitigated (Boras et al. 1990). Nevertheless, in spite of these complications, utility commissions are currently quantifying, valuing, and considering externalities in their planning schemes. These environmental externalities have focused on the impact of electricity generation on:

- Humans (morbidity and mortality);

- Crops, forests, and fisheries (losses and damages);

- Materials (corrosion and soiling); and

- Climate (change), recreation (diminishment), and visibility (impairment).

The largest contributions to environmental costs that electricity generation imposes on society are those resulting from the risks to human health (i.e., increased risk of mortality and morbidity, including acute effects, exacerbation of chronic illness, and increased risk of developing chronic disease).

A significant amount of research involving environmental externalities exists along these lines. All of these studies assume that environmental risks imposed by energy resources result in costs paid by someone, regardless of whether estimates of those costs are quantified. Moreover, these costs are extremely difficult to calculate in terms of damage determined on the basis of valuations of life and in terms of nonmonetized costs like valuation of recreational and cultural facilities. Thus, the valuation of environmental externalities is considered to be very difficult and is perceived by many researchers in the field as a discipline in its infancy, even though the concept has been around for decades (Freeman 1985; Joskow 1991; Lave 1991). 


\section{THEORETICAL APPROACH TO THE VALUATION OF ENVIRONMENTAL EXTERNALITIES}

\subsection{GENERAL RELATIONSHIPS TO BE CONSIDERED}

To quantify the relationship between power plant emissions resulting from electricity generation and the valuation of deleterious effects, several functional relationships must be established and specified (Figure 1). These include the following:

1. The relationship between specific power plant emission quantities and their resulting ambient pollution concentrations;

2. The relationship between ambient pollution concentrations and their health/environmental burden;

3. The relationship between the health/ environmental burden and any and all physical or biological effects; and

4. The relationship between physical or biological effects and their monetary valuation.

Relationship 1 includes the dispersion and transport of point-source emissions, because these emissions become part of the ambient air and contribute to its quality. The health/environmental burden in relationship 2 specifically refers to the level of exposure or dose that affects living organisms, materials, and the biosphere in general. The physical or biological effects in relationship 3 refer to specific health effects, health risks, and environmental impacts, such as death, injury, respiratory ailments, slower plant growth, loss of habitat, materials corrosion or soiling, and degradation to scenery. In relationship 4, monetary valuation - according to the willingness to pay or the willingness to be compensated for the risk accepted voluntarily - refers to the methods that may be used to assign values to the predicted changes in mortality, morbidity, etc. (Freeman 1979; Ottinger et al. 1990).

Any approach to measuring health/environmental costs and benefits involves some method of determining these relationships. Especially critical is relationship 2. This 
relationship may be used to predict changes in mortality or morbidity rates associated with changes in ambient concentrations of pollutants or exposure to them.

\subsection{SITE-SPECIFIC RELATIONSHIPS TO BE CONSIDERED}

To complicate matters even more, damages are site specific. Any health-related damages depend on the number of people exposed and the composition of the exposed populations (in terms of age, existing infirmities, living conditions, social habits, etc). Hence, health/environmental damages can vary considerably from site to site, depending on:

- The location of the source relative to the population;

- The area's meteorology and topography, which influence pollutant dispersion; and

- The type and amount of vegetation and the number of bodies of water in the area and their ability to absorb the pollutants generated (Ottinger et al. 1990).

The relationship between a particular site's population density and concentrations of ambient air pollution is critical in that:

- The size of the affected population affects the total number of incidences of premature death and morbidity, which critically affects the cost (externality value) of pollution (by specific pollutant);

- The amount of material to which the affected population is exposed is often assumed to be proportional to the size of the exposed population; and

- Visibility costs are calculated on a per-capita basis and then multiplied by the total population (Ottinger et al. 1990).

\subsection{GENERAL FACTORS TO BE CONSIDERED}

Numerous factors play a role in the theoretical approach and need to be weighed in any application. These factors are briefly mentioned in the following subsections.

\subsubsection{Factors Related to Risk and Value of Life}

- Environmental risks imposed by energy resources result in costs that are paid by someone, whether or not these costs can be quantified (Ottinger et al. 1990). 
- Some economists and risk analysts consider applying a discount rate similar to that used in any economic cost-benefit analysis. However, particularly with respect to the morality of risks to human life and health, a life in the future should be considered as valuable as a life today (Shuman and Cavanagh 1982). Therefore, the value placed on future lives and other environmental assets should probably be weighted the same as is the value placed on present lives and envirunmental assets.

- Assigning 2 dollar value to the risk to life should not and does not imply that loss of life is treated strictly as an economic commodity. In other words, econorilists and risk analysts assign a value to the risk to human health; they do not assign a value to a specific human life. It is the risk of mortality or morbidity that is shared by all members of the exposed population that is relevant for economic valuation purposes. Specifically, the economic value of health risks consists of either society's willingness to pay to avoid the risk or its willingness to be compensated for suffering as a result of the risk. The economic value of a health risk is not the value of a certain death; it is the value of a risk sliared by members of an exposed population, and it is determined on the basis of the premise that everyone shares the risk but that the specific individuals who will die or be injured are not known.

- Because environmental effects are complex, because there may be a long time lag between emissions and response, and because it is unlikely that the actual victims of an energy resource's environmental effects can be identified, the precise environmental effects caused by an energy resource may never be known (Viscusi 1989).

- Although economic valuations of environmenial risks are emphasized here, if risks are to be better understood, understanding of the changes in physical and biological relationships that result from environmental impacts of energy resuurces must be more complete. For example, exactly which crops will be damaged, which forests will be denuded, or whose recreational opportunities will be diminished cannot be known (Ottinger et al. 1990). However, it is a fact that crops, forests, recreational opportunities, and human health are at risk.

\subsubsection{Factors Related to Valuation of Risk}

- Although early attempts to derive values for health risks were based primarily on an accounting of the damages expected as a result of increased medical expenditures, loss of income and other economic products, and decreases in quality or quantity of life, health care costs are not considered an adequate measure of the value of risk to life. 
Medical costs, loss of earnings (or earning potential), pain and suffering, lost work experience, and lost productivity from human impairment are considered to be far too low in value for measuring the value of risk to life (Schulze et al. 1983; Ottinger et al. 1990).

- It is difficult to calculate damage costs on the basis of valuation of life and nonmonetized costs like the valuation of recreational/cultural facilities, and this difficulty is likely to persist (Ottinger et al. 1990). Moreover, damage estimates are not expected to be identical from one continent to another, nor will they necessarily be identical within continents. Impact levels, the effects of impacts on natural systems, and the valuation of impacts will all vary both within and among continents. External effects that are local or regional in nature should probably not be assumed to apply to another country, or any part thereof, unless there is thorough justification (Grahame 1991).

- Control costs are not equal to damage costs. The costs of controls required in the past to correct historical environmental problems are not directly relevant to determining the value of reductions in pollution today, especially if the environment in a particular industrialized country (specifically air quality) is now much cleaner. Regarding future measures, the incremental cost of the required control for that pollutant provides a reasonable value for reducing emissions of that pollutant at the margin.

- The marginal control cost represents the highest cost that industrialized society has indicated it is willing to pay for recent or future reductions of an externality. But the marginal cost of control is probably lower than the true societal value of reducing an externality at the margin. Thus, the externality estimates generated through the use of the marginal cost of abatement are considered conservative (low) estimates of the actual marginal values of reducing the externalities (Chernick and Caverhill 1991). Nevertheless, the basic cost of controls in Asian countries, where air quality is much poorer and daily exposure to risk is much greater, may serve as an appropriate starting point in assessing damage costs.

\subsubsection{Factors Related to the Specific Cost of Abatement}

- Any given target level of emissions of a particular pollutant should be achieved at the lowest possible abatement and mitigation cost. In other words, as few resources as necessary should be spent to achieve any 
particular environmental goal (Joskow 1991). Several conditions must be met to achieve least-cost emissions control:

- All sources producing a particular pollutant in a region must be covered by consistent emissions constraints.

- Each source must achieve its required level of emissions reduction at the lowest possible cost. There may be large variations in the efficiencies and the costs of control technologies across sources.

- The marginal cost of control must be equalized across all sources. (The curve that routinely appears in environmental texts to represent the marginal cost of control is a curve that represents the least cost of control and implicitly assumes that all of the above conditions are met.)

- The optimal emissions level for a particular pollutant in a relevant pollution region should be selected by balancing the incremental benefits, or the damages avoided by reduced emissions, against the (least-cost) incremental cost of reduced emissions (Joskow 1991). (Abatement expenses reflected in the product price define both the optimal level of abatement from uncontrolled levels and the social value or price of additional pollution.)

- The prices and quantities of final goods should reflect the costs of meeting the emissions levels. The least-cost abatement and mitigation strategies implied above and the societal value of residual emissions resulting from a marginal increase in output evaluated at the optimal emissions level should be used. When prices are raised, demand is reduced, and any given level of emissions reduction can be achieved at a lower cost than if prices and demand are assumed to be fixed (Joskow 1991). 


\section{RESEARCH CONTRIBUTING TO THE UNDERSTANDING OF ENVIRONMENTAL EXTERNALITIES}

\subsection{RESEARCH ON AIR POLLUTANTS THAT AFFECT HUMAN HEALTH}

Many air pollutants affect human health, generally by affecting respiratory functions and causing symptoms such as impaired breathing, coughing, chest tightness, and reduced productivity and activity. High levels of air pollutants are generally associated with altered pulmonary ventilation (especially in children, the aged, and the infirm), increased frequency and severity of asthmatic attacks, increased prevalence of chronic respiratory disease, and increased mortality.

To date, recognized control methods have generally focused on suspended particulates and sulfur oxide $\left(\mathrm{SO}_{\mathrm{x}}\right)$ emissions. Sulfur dioxide $\left(\mathrm{SO}_{2}\right)$ itself is not generally

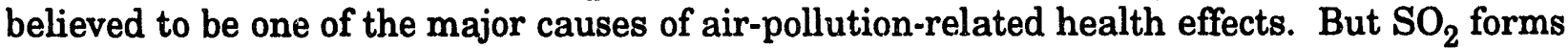
sulfates and acid aerosols that are considered harmful above certain ambient levels. More importantly, particulates (especially small ones less than 10 micrometers [microns or $\mu \mathrm{m}$ ] in diameter) are most often recognized as the major cause of air-pollution-related health effects. Nitrogen oxides $\left(\mathrm{NO}_{\mathrm{x}}\right)$, although not considered harmful in themselves, play a role in the formation of ozone in subsequent chemical reactions during the transport and dispersion phase. At high levels, ozone is reported to severely damage human health, vegetation, and materials (Ottinger et al. 1990).

\subsubsection{Sulfur Dioxide}

Sulfur dioxide is a corrosive gas that is hazardous to human health and has deleterious impacts on the environment. It is emitted by both natural and anthropogenic processes. Natural sources include volcanoes, decaying organic matter, and sea spray. Anthropogenic sources of $\mathrm{SO}_{2}$ include combustion of sulfur-containing fuels and smelting of nonferrous ores. Electricity generation through use of fossil fuels is the largest single source of $\mathrm{SO}_{2}$ emissions in many industrialized countries (WRI and IIED 1988).

Emissions of $\mathrm{SO}_{2}$ contribute to ambient levels of small particulates by reacting in the atmosphere to form sulfates and acid aerosols. The sulfates are believed to be a significant portion of small particulates, in terms of both volume and toxicity to humans. Acid aerosols have not been shown to definitely endarger public health, but important circumstantial and qualitative evidence - representing the weight of science and evolving from animal toxicology, human clinical studies, and epidemiology - points to potential health effects from

acid aerosols at or near ambient levels. Moreover, there appears to be a synergistic effect between $\mathrm{SO}_{2}$ and acid aerosols (Ottinger et al. 1990).

Lave and Seskin (1977) reported that a decrease of 0.092 part per million (ppm) in the mean concentration of $\mathrm{SO}_{2}$ in Chicago is associated with 6.3 fewer deaths per day. Damages from $\mathrm{SO}_{2}$ emissions imply health-effect values ranging from $\$ 1.34$ to $\$ 17.20$ per 
pound of $\mathrm{SO}_{2}$, values that indicate there is considerable uncertainty in estimating and valuing damages due to $\mathrm{SO}_{2}$. The costs to humans and their environment from $\mathrm{SO}_{2}$ emissions may be found to be significantly higher once all effects are taken into account (Otث̃inger et al. 1990).

\subsubsection{Particulates}

Solid and liquid materials suspended in the air - particulates - range from fine suspended aerosols to large particles of grit. Particulates may cause human respiratory effects, materials damage (soiling and corrosion), and impaired visibility.

The impact of particulate matter varies with its size and composition. In general, small particulates (less than $10 \mu \mathrm{m}$ in diameter) are more hazardous to human health because they enter the human respiratory system more easily than larger particles. These small particulates cause eye and lung damage and aggravate existing respiratory diseases (WRI and IIED 1988). However, larger particles $(>10 \mu \mathrm{m})$ are more important in soiling. All particulates contribute to visibility impairment (Ottinger et al. 1990).

The major components of particulate emissions from coal-fired power plants are ash, heavy metals (mercury, arsenic, cadmium, chromium, lead, and others), radioactive isotopes, hydrocarbons, and sulfates and nitrates; these last two are formed as a result of $\mathrm{SO}_{2}$ and $\mathrm{NO}_{\mathbf{x}}$ reacting in the atmospinere (Szpunar et al. 1980).

\subsubsection{Nitrogen Oxides and Ozone}

Nitric oxide (NO) is emitted by several natural and anthropogenic processes; NO is then rapidly converted to nitrogen dioxide $\left(\mathrm{NO}_{2}\right)$ in the atmosphere. $\left(\mathrm{NO}_{\mathrm{x}}\right.$ is used to denote these two nitrogen oxides - $\mathrm{NO}$ and $\mathrm{NO}_{2}$.) Nitric oxide is formed naturally by lightning; it is also emitted by microorganisms involved in the breakdown of organic matter. Anthropogenic $\mathrm{NO}_{\mathrm{x}}$ emissions result from high-temperature combustion (e.g., from automobile engines). The transportation and electric utility sectors are the most important anthropogenic sources of $\mathrm{NO}_{\mathrm{x}}$ (WRI and IIED 1988).

Ozone is the primary element of urban smog and regional haze. It is formed in the lower atmosphere (troposphere) by reactions among $\mathrm{NO}_{2}$, carbon monoxide (CO), oxygen, and hydrocarbons other than methane. These reactions are triggered by sunlight (WRI and IIED 1988). In the troposphere, ozone reduces the filtering power of the atmosphere. Nitrogen oxides emitted from point sources react in the atmosphere in sunlight to form ozone, smog (including the particulates PAN [peroxyacetyl nitrate] and PPN [peroxyprionyl nitrate]), and acid rain (from nitric acid $\left[\mathrm{HNO}_{3}\right]$ ). Increased tropospheric or 
ambient ozone ${ }^{4}$ can cause severe damage to human health, vegetation, rubber, and other materials. Thus, ozone-related damages can be linked directly to regional $\mathrm{NO}_{\mathrm{x}}$ emissions (Ottinger et al. 1990).

High short-term concentrations of ozone, which may be reversible (Grahame 1992), cause lung irritation, hyperactivity, eye irritation, respiratory inflammation, coughing, lung function reduction, and inhalation pain. Long-term exposure to ozone causes chronic lung disease, lung cancer, and increased susceptibility to bronchitis and pneumonia.

Together, $\mathrm{NO}_{\mathrm{x}}$ and ozone contribute to the initiation of chronic respiratory problems, aggravate existing respiratory conditions, and increase the susceptibility of the ill and elderly to life-threatening pneumonia. Frequent strenuous activity outdoors increases the ozone dose of an individual; children and the elderly are especially susceptible (Jacobson 1984). Reportedly, $90 \%$ of inhaled ozone is never exhaled.

Moreover, ozone may be the largest contributor to pollution-related crop damage. Both ozone and PAN damage crops and natural vegetation; PAN primarily affects herbaceous crops. Ozone injures plant tissues, inhioits photosynthesis, and increases the susceptibility of crops to other pollutants, disease, and drought. Dverall, U.S. crop yields are probably depressed by $5-10 \%$, which represents an estimated economic loss of $\$ 1-2$ billion annually.

The co-occurrence of ozone with $\mathrm{SO}_{2}$ and $\mathrm{NO}_{\mathrm{x}}$ can increase the susceptibility of vegetation to damage. U.S. studies indicate that $\mathrm{SO}_{2}$ may increase the sensitivity of plants to leaf injury by ozone. Research in West Germany and the Netherlands indicates that combinations of ozone, $\mathrm{SO}_{2}$, and $\mathrm{NO}_{2}$ may reduce dry matter production in vegetation more than does ozone alone. Oxidants such as ozone can make trees more vulnerable to disease, interfere with photosynthesis, and damage leaf cells, thereby increasing the loss of nutrients. Oxidant damage is the likely culprit when the foliage yellows from the top down and drops off. Peak ozone concentrations experienced in the United States are toxic to tree seedlings (WRI and IIED 1988).

\subsection{EPIDEMIOLOGICAL STUDIES}

Many epidemiological studies have focused on the effects of air pollution on human health. Lave and Seskin (1977) used multiple regression techniques to investigate the relationships between a variety of air pollution variables and mortality rates. The air pollution variables they used were intended to represent long-term or chronic exposure for typical residents of U.S. urban areas. The pollution measures used in the regressions, along with other possible causal variables, explained the mortality rate for each urban area studied. Lave and Seskin found a quantitative association between air pollution and morbidity and

4 Tropospheric (lower atmosphere) or ambient ozone is not to be confused with stratospheric (upper atmosphere) ozone. The concentration of stratospheric ozone, which is beneficial, is said to be decreasing because of chlorofluorocarbon buildup and increased fossil fuel combustion; this decrease may contribute significantly to global warming. 
mortality. Furthermore, their evidence was the first to support the hypothesis that increased exposure to air pollutants leads to higher mortality rates (Freeman 1979; Lave and Seskin 1977). Recently, French (1990) reported in Worldwatch that in cities like Athens, Bombay, and Beijing, on days with severe air pollution, death rates were markedly higher.

During the 1970s, Lave and Seskin, the U.S. Environmental Protection Agency (EPA), and many others conducted major epidemiological studies on the effects of air pollution on human health. Most of these studies increased the body of knowledge about dose-response functions (Freeman 1979, 1982). However, the majority of these studies did not attempt to predict changes ir mortality or morbidity or assign damage values. Examples include Wadell (1974); the Heintz et al. (1976) reference cited in Freeman (1985); and the following references cited in Freeman (1979 or 1982): Liu and Yu (1976), Small (1977), Viren (1978), Crocker et al. (1979), Morris et al. (1979), and Thibodeau et al. (1980).

\subsection{STUDIES ON VALUING HEALTH RISKS}

In the last two decades, many studies have been conducted to value health risks, specifically those from electricity generation. Many of these studies base their values on wage/risk compensation. The health-risk values per statistical life ${ }^{5}$ range from $\$ 440,000$ to $\$ 12,800,000$ (all adjusted to 1989 U.S. dollars). Examples are listed in Table 1. At least one str dy (Amaral 1988) has suggested and demonstrated a method for representing uncertainty, specifically to aid policymakers in making decisions about health risks from electricity generation.

\subsection{STUDIES ON MONETIZING ENVIRONMENTAL EXTERNALITIES}

Chernick and Caverhill (1991) provide a rationale for monetizing externalities. They suggest that estimating a monetary value for environmental externalities provides an approximation of the societal value of reducing impacts on human health and the environment from electricity generation. They estimate these monetary values for environmental externalities not from direct damage estimates but rather from indirect proxies. Through monetization, these externalities are expressed as a cost per unit of the externality, such as dollars per ton of emissions.

5 According to Ottinger et al. (1990), "Health risk values are often expressed as values per human life. This is convenient but inaccurate terminology. Aggregating values to a single life facilitates comparison, but it creates the impression that human life itself is being valued. Risk values are typically calculated for very small risks. An analyst may determine, for example, that each increment of risk of $1 / 100,000$ probability of fatality has a value of $\$ 40$. If that risk were imposed on a population of 100,000 , it would be expected that one person would die. Since that amounts to 100,000 people each with a $\$ 40$ value, the total risk value would be $\$ 4,000,000$. Thus, the value for the statistical life would be $\$ 4,000,000$." This term is also discussed by Freeman (1982). 
TABLE 1 Research on Valuing Health Risks from Electricity Generation

\begin{tabular}{|c|c|c|}
\hline \multirow[b]{2}{*}{ Source } & \multicolumn{2}{|c|}{$\begin{array}{c}\text { Health Risk Value per } \\
\text { Statistical Life (1989 U.S. \$) }\end{array}$} \\
\hline & $\begin{array}{l}\text { Low Vaiue of } \\
\text { Range or Point } \\
\text { Value }\end{array}$ & $\begin{array}{c}\text { High } \\
\text { Value of } \\
\text { Range }\end{array}$ \\
\hline Smith (1976) & $9,400,000$ & $\mathbf{a}$ \\
\hline Thaler and Rosen (1976) & 700,000 & \\
\hline Viscusi (1979) & $3,600,000$ & $4,900,000$ \\
\hline Brown (1980) & $1,300,000$ & $1,900,000$ \\
\hline Black and Niehaus (1980) & 500,000 & 775,000 \\
\hline Olson (1981) & $9,100,000$ & \\
\hline Shuman and Cavanagh (1982) & 440,000 & $4,400,000$ \\
\hline Viscusi (1983) & $8,500,000$ & $12,800,000$ \\
\hline Schulze et al. (1983) & 455,000 & $1,340,000$ \\
\hline ECO Northwest (1987) & $3,300,000$ & \\
\hline Moore and Viscusi (1988a) & $4,600,000$ & \\
\hline Moore and Viscusi (1988b) & $5,300,000$ & $6,400,000$ \\
\hline Kowalczyk et al. (1988) & $11,000,000$ & \\
\hline
\end{tabular}

a A blank space indicates that only a point value was provided.

Chernick's and Caverhill's (1991) preferred technique is to calculate implied valuation by estimating the marginal cost of abatement. In other words, the implied societal value of reducing the pollutant is based on the maximum cost society has committed (or appears about to commit) to pay to achieve the reductions.

In contrast to the Chernick and Caverhill proxy value estimation approach, cost estimates of direct damage have been made for environmental externalities such as air and water pollution. The relevant effects might include impacts on:

- Human life and health;

- Domesticated plants and animals, such as commercial forests, crops, lawns, and livestock;

- Wild plants and animals in a variety of habitats;

- Nonliving materials, such as those exposed on buildings, at archaeological and historical sites, on monuments, on vehicles, and in natural landforms; and

- Human comfort and pleasure, including effects of noise levels, visibility, and odors. 
Direct estimation of environmental externalities requires determination of how the pollutant moves through the atmosphere, how it changes chemically (especially for precursors to ozone and to particulates), how it is deposited on various surfaces (lungs, soil, water, paint, etc.), how much it affects each system (including human health, crops, wildlife, materials, visibility, and others), and the unit value of the effects on each system. In fact, the transport calculations are very complicated, and the atmospheric chemistry and dose-response relationships can be highly uncertain. Also, as already mentioned, it is very controversial to assign values to human morbidity and mortality (which are themselves complicated by age, health, duration of illness, and the extent of suffering and dread) as well as to historic monuments, forests, wildlife, ecosystems, and visibility.

Implied valuation relies on the costs of required or anticipated regulations or control measures to estimate a societal value for reducing emissions of particular externalities. In other words, what are U.S. residents (or others) willing to pay, on a national or regional basis, to reduce $\mathrm{SO}_{2}, \mathrm{NO}_{\mathrm{x}}$, volatile organic compounds, and toxic air emissions? International, federal, and state regulations provide estimates of the value of reducing externalities at the margin by using shadow pricing or revealed preference and marginal cost of abatement. Also, despite the assertion stated earlier (i.e., that control costs are not equal to damage costs), there is increasing use of the cost of abatement to determine the value of reducing externalities, specifically in California, New York, Massachusetts, and Nevada.

The marginal value is an estimate of the value of marginal improvements in air quility because it relates point sources to improvements in ambient air quality. By so doing, the marginal cost of abatement represents a minimum estimate of the marginal value of reducing emissions, to the extent that society will be able to avoid expenditures for the most expensive control measures for new plants or future retrofits.

Thus, the marginal control cost represents the highest cost society has indicated it is willing to pay for recent or future reductions of a cost externality. As already discussed, the marginal cost of control is probably lower than the true societal value of reducing an externality at the margin. Thus, the externality estimates generated through the use of the marginal cost of abatement are conservative (low) estimates of the actual marginal values of reducing the externalities (Chernick and Caverhill 1991). However, marginal benefits of control may never be known with absolute certainty, because:

- All externalities may not be identified,

- Accurate dose-response functions may not be available, and

- The value of externalities may not be properly assessed (Grahame 1991). 


\subsection{STUDY ON ELIMINATING OR IMPROVING THE ENVIRONMENTAL EXTERNALITIES APPROACH}

For a variety of detailed, theoretical, economics-related reasons, Joskow (1991) has been advocating the elimination of the environmental externalities approach currently used by a number of state public utility commissions. If his call for dismissal remains unheeded and the approach continues to be used, he has some very helpful suggestions for improving upon the approach. These are as follows:

- Base environmental externalities on the best estimates of the incremental damages caused by the various emissions, not on the highest cost of control methodology, which may be considered meaningless and arbitrary.

- Examine the extent to which existing environmental regulations already internalize the external costs, recognizing that residual damages and "unpriced" externalities are not the same thing when emissions are already subject to regulation. This examination may require complicated analysis.

- Evaluate the effects of using externality values in the context of the actual operation of existing environmental regulations as they affect both new and existing sources. This evaluation will help to ensure that the values do not have unintended adverse environmental effects and that they are compatible with future changes in environmental laws. In essence, avoid double counting.

- Account for unintended effects resulting from the fact that the constraints are usually limited to electricity produced and sold within a single state's boundaries and that these constraints may increase the incentives for self-generation.

\subsection{LEAST-COST PLANNING EFFORTS}

True least-cost planning, used in evaluating power-generation alternatives, conceptually requires the consideration of externalities. The first step in internalizing social or external costs is to understand them; the next step is to identify and quantify them. Attempting to fully describe the entire range of effects connected with specific resources is difficult. Placing a value on each individual effect is considerably more difficult, particularly because external costs fall outside the normal market pricing systern. Since little real information on market costs is available to use as guidance, it may be necessary to devise entirely new methods of collecting and assessing information. Certain factors may resist quantification entirely and may require relatively subjective assessments. 
Deciding which impacts and costs to consider is most difficult. The breadth and depth of the categories selected for evaluation and the way in which they are defined have a tremendous impact on the outcome of any evaluation of social costs. Accurately attributing costs to their sources is not yet a finely developed science, and the process itself may influence which parameters are selected. The specific definitions or assumptions made introduce significant complexity into the calculation of social costs and later determine the rates at which some social costs are traded off against others, thus affecting which impacts are mitigated. Determining how to define and weight the importance of social costs and benefits resulting from economic development is therefore a highly complex and subjective process.

Some analysts, such as Hohmeyer of Germany, believe that incorporating social costs into energy planning might best be accomplished through the imposition of a tax or penalty with a cost that is equal to or greater than the social cost. However, few analysts would suggest that social costs should be directly paid by anyone; rather, they would suggest bidding systems as one way to incorporate social costs into the utility decision-making process. This incorporation would allow a determination of if and how social costs change the order in which resources are selected. The result could be that a utility board or authority would select a power source that has slightly higher energy and/or capacity costs, resulting in lower social costs (Finnell et al. 1990).

Externality costs must be taken into account when future energy options are being chosen. Hohmeyer (1988) believes that if, externalities had been included in West Germany's coal and nuclear options, the cost of coal production would have increased by $80 \%$ and that the cost of nuclear power would be three times its current price to consumers. Hohmeyer believes that the failure to include external costs in the marketplace puts renewable energy systems at a systematic disadvantage. If the social costs had been included in the market prices of conventionally generated electricity, wind energy would have become cost effective in 1984, according to Hohmeyer. By ignoring social costs, "The introduction of renewable energy technologies has been delayed by 7 to 15 years for wind and 4 to 10 years for photovoltaics" (Hohmeyer 1988).

The generation of electricity at power plants imposes a variety of burdens on the environment (e.g., emissions of atmospheric pollutants), which, through a variety of pathways and interactions, can cause damage to human health, ecosystems, economic productivity, and cultures. Although these impacts often occur far from the sources of pollution, both spatially and temporally, they are a genuine cost of electricity production and use. Whether through the damages sustained or through effo:ts to remediate the damages, these costs are ultimately borne by society, even if that burden is not distributed equally across space (geography) or over time (generations). Moreover, environmental costs that are not currently internalized may become so later, as policies and regulations are changed to reduce pollutant loadings (Bernow et al. 1991). Thus, least-cost planning must take into account these considerations. 


\section{SIMPLIFIED APPROACH FOR VALUATION OF ENVIRONMENTAL EXTERNALITIES}

As long as the results and qualifiers already discussed in this report and those of other studies are kept in mind, a simplified approach is proposed to determine monetary values for damages in the area of environmental externalities (Figure 2).

1. Calculate power-plant-generated emissions from various electricity-generating options (especially coal-fired options), recognizing their inherent uncertainties. These calculated emissions will depend on plant type, plant age, fuel type, fuel grade, sulfur content, installed/operating emissions technology, and plant operating parameters such as heat rate, combustion temperature, and injection options.

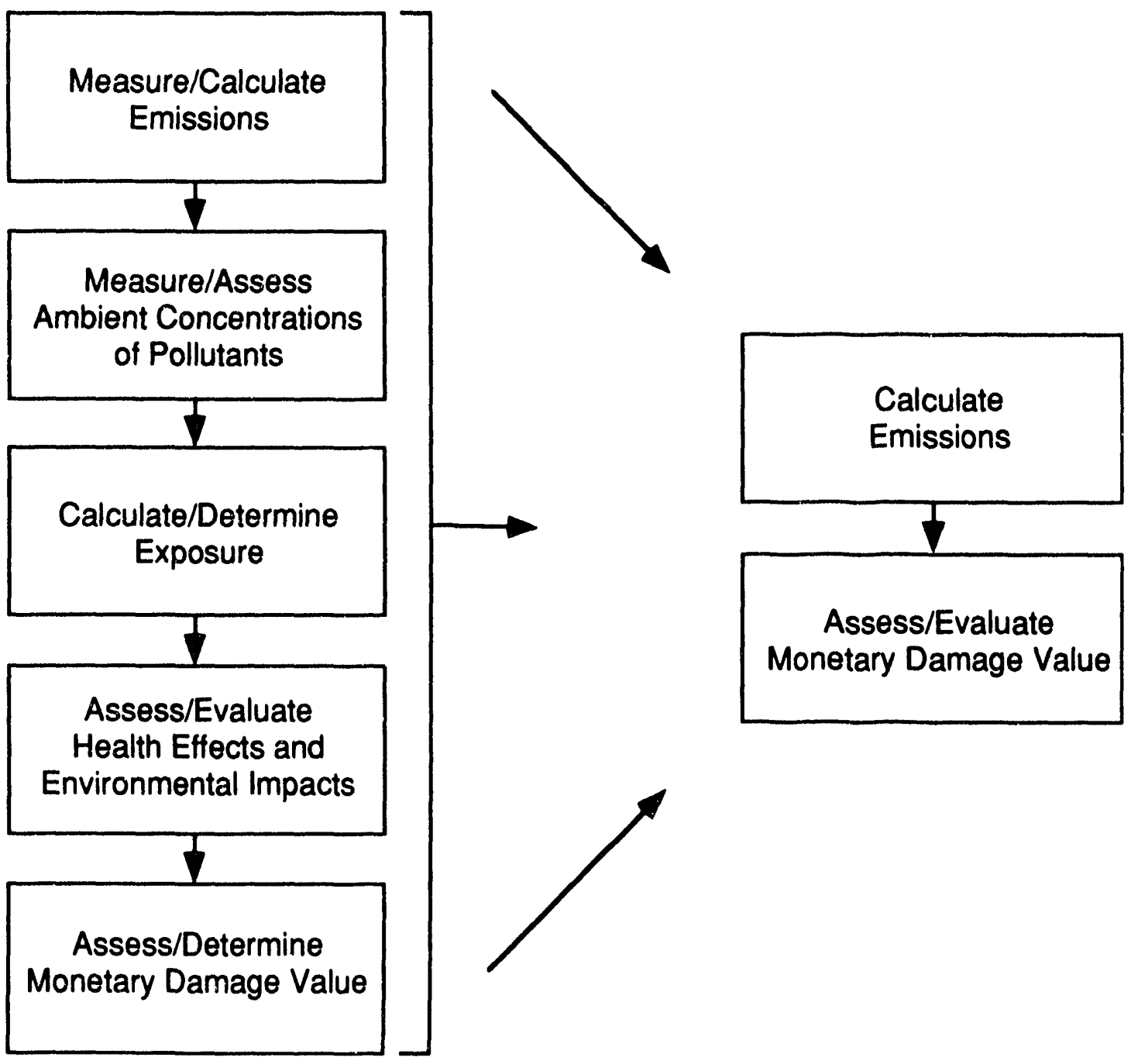

FIGURE 2 Simplified Approach Derived from a Theoretical Approach 
2. Assess the value of monetary damage to the environment, assuming conservative estimates for point-source emissions.

\subsection{MEASURING ASIAN AIR QUALITY CONDITIONS}

The extent to which air quality is monitored in most of Asia remains limited. With the exception of Japan, air quality in Asia has generally worsened with industrialization and the lack of effective pollution controls. Not one United Nations Environment Programme/World Health Organization (UNEP/WHO) site in Asia for monitoring air quality has yet complied with WHO standards for suspended particulates, and only half the stations met $\mathrm{SO}_{2}$ standards between 1979 and 1985. (The WHO standards are analagous to the U.S. National Ambient Air Quality S'tandards [NAAQS].)

Overall, air quality in Asia is said to exhibit no definitive trends; progress made in some cities to decrease certain pollutants is offset by setbacks in others. When compared with the industrialized countries (Tables 2 and 3), Asia lags far behind in controlling most air pollutants. For example, particulate levels in Manila increased more than 20\% from 1974 to 1984 (WRI and IIED 1988).

Taiwan's considerable efforts in industrialization and economic development caused its air pollution concentrations to increase dramatically during the 1960s and 1970s (Chow et al. 1983), principally because of:

- A substantial increase in the number of industries;

- The continued combustion of fuel oil, coal, and wood;

- An increase in automobile exhaust emissions; and

- A high population density.

Preliminary measurements of pollution in the heavily industrialized city of Kaohsiung appear to show that it is comparable to pollution in other Asian industrial centers, as indicated in Tables 2 and 3, which illustrate ambient air conditions for particulates and $\mathrm{SO}_{2}$. Although these data are somewhat dated, they illustrate the fact that the ambient air quality in Taiwan generally exceeds WHO guidelines for both $\mathrm{SO}_{2}$ and particulates. Chow et al. (1983) call for long-term monitoring that uses standardized procedures at more sites.

\subsubsection{Particulates}

All 10 cities with the highest levels of particulates in the world are in developing countries of Asia; of the 10 cities with the lowest concentrations in the world, nine are in industrialized countries. This difference may reflect the natural conditions of cities in the dev.loping countries (i.e., some of these cities have high levels of naturally occurring dust) as well as the stricter emissions controls in force in cities of the industrialized world. 


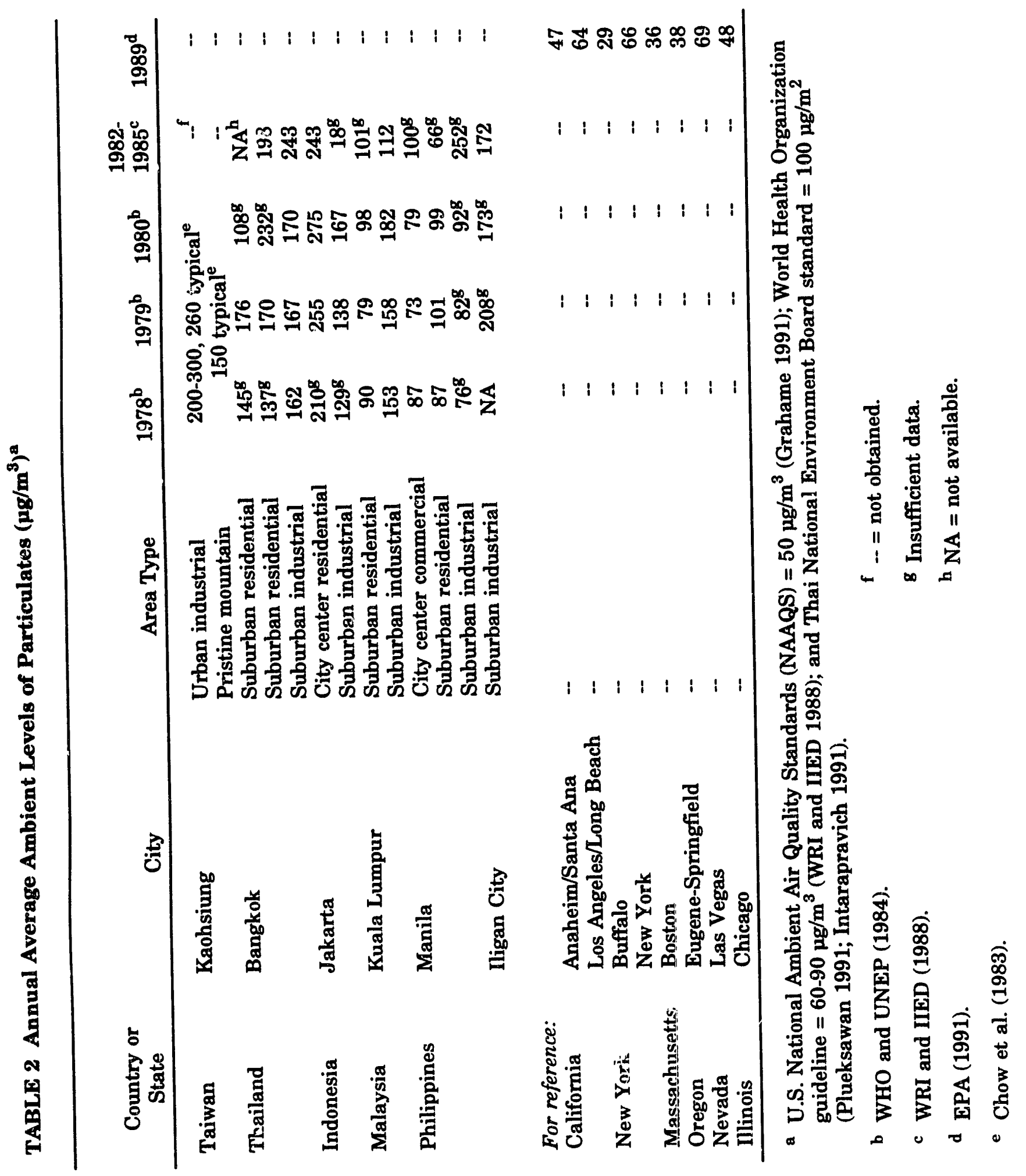




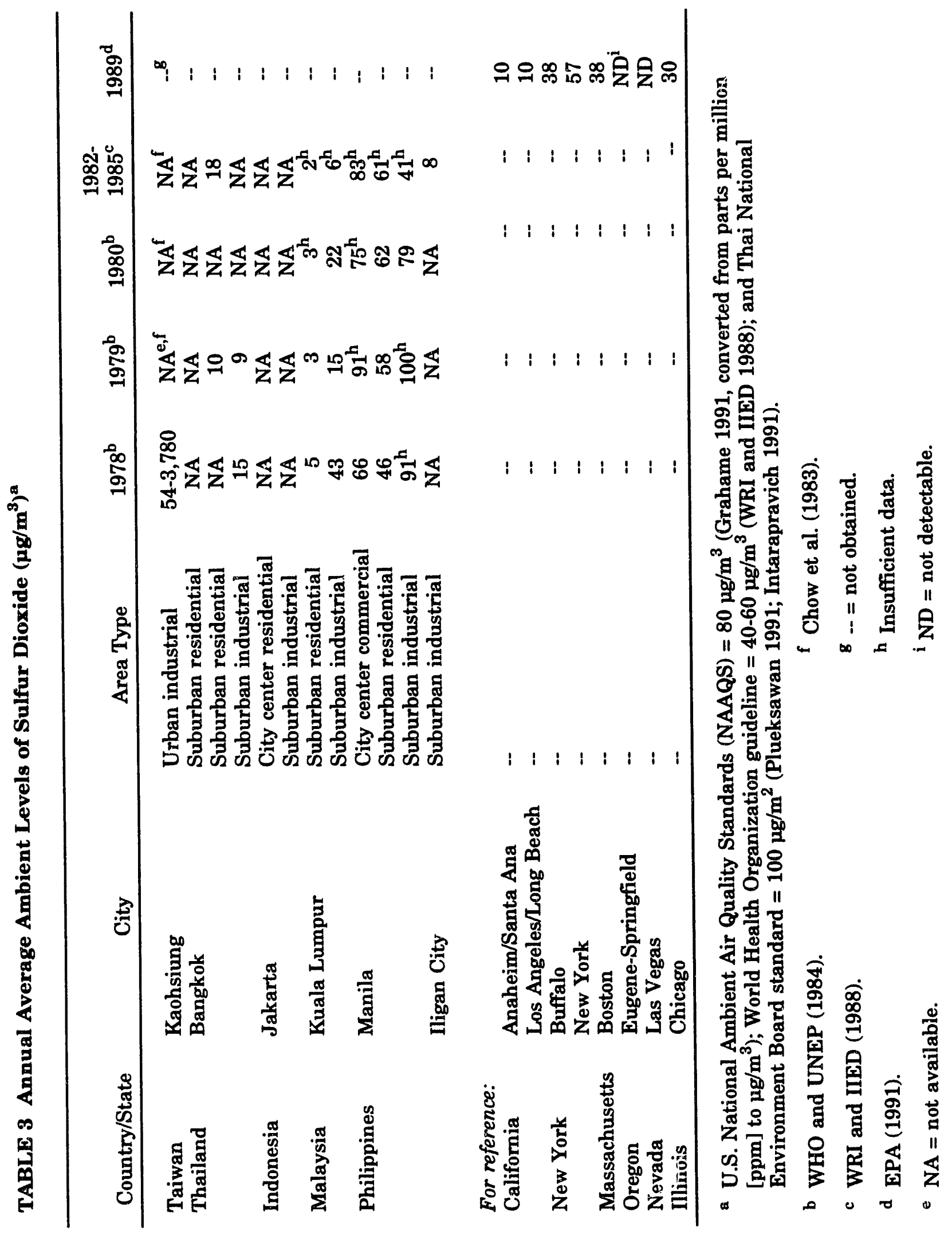


Average and peak concentrations of particulates exceeded the air quality standards recommended by the WHO at 62 of the 73 monitoring sites in developing countries. Only eight South American monitoring sites and no Asian sites had particulate levels that fully complied with WHO standards. By comparison, about half the stations in industrialized countries were in compliance with WHO standards.

Particulate levels in some Asian cities exceeded the standards by factors of three to five. The forecasted trend in particulate pollution is ambiguous, since more stations showed declines in average particulate levels but increases in peak values (WRI and IIED 1988).

In 1984, Taiwan was reported to have 170 monitoring stations, but most of these stations were reported to contain only manual particulate measuring devices. A monitoring center, 19 automatic all-criteria stations, and one mobile van were said to have been planned (Chuang and Shen 1986). At that time, particulate emission levels from stationary sources were reported to show a decreasing trend, while the amount of pollutants from mobile sources was reportedly on the rise. Taiwan has been chaiacterized as being moderately polluted and about 15 years behind Japan in its environmental protection efforts. Moreover, Tsai and Jenq (1988) report that candidate locations for air quality monitoring sites are still under study (perhaps as refinements) for Taipei (Tsai et al. 1991).

During 1982-1985, Bangkok (198-243 $\left.\mu \mathrm{g} / \mathrm{m}^{3}\right)$, Jakarta $\left(243 \mu \mathrm{g} / \mathrm{m}^{3}\right)$, and Manila (100-172 $\mu \mathrm{g} / \mathrm{m}^{3}$ ) all exceeded the WHO guideline of $60-90 \mu \mathrm{g} / \mathrm{m}^{3}$ by more than two to three times; Kuala Lumpur (100-112 $\mu \mathrm{g} / \mathrm{m}^{3}$ ) also exceeded the guideline (Table 2).

\subsubsection{Sulfur Dioxide}

Most $\mathrm{SO}_{2}$ monitoring is motivated by health concerns and is therefore conducted in urban and suburban areas. Thus, "national" monitoring programs may not represent rural regions, where power plants are likely to be located.

Levels of $\mathrm{SO}_{2}$ pollution in cities of developing countries do not appear to be as high as levels of particulate pollution; about half the stations recorded $\mathrm{SO}_{1}$ levels that exceeded WHO standards. About $15 \%$ of the stations in industrialized countries also exceeded the standards. Trend data indicate neither a broad improvement nor a worsening of $\mathrm{SO}_{2}$ pollution; approximately equal numbers of stations reported increases and decreases in $\mathrm{SO}_{2}$ over the 1979-1985 period (WRI and IIED 1988).

Recently, calculations for an East Asian (Japan, mainland China, Taiwan, South Korea, and North Korea) emissions inventory indicated that $\mathrm{SO}_{2}$ emissions from Taiwan are similar to those from Japan and South Korea, with the principal emission sources concentrated in the Taipei, Jilong, and Gaoxiong areas (Fujita et al. 1991).

During 1982-1985, of the Asian countries, only Manila (61-83 ug/m $\mathrm{m}^{3}$ ) appears to have exceeded the WHO guideline of $40-60 \mathrm{ug} / \mathrm{m}^{3}$. However, data appear to be sparse (to nonexistent) for Bangkok and Jakarta (Table 3). 


\subsubsection{Ozone}

Apparently, tropospheric ozone pollution is monitored by only a few countries. More than half the stations reported annual mean ozone concentrations in excess of the Canadian standard (15 parts per billion [ppb]) in 1979 to 1985.

In the United States, a $13 \%$ decline in peak ozone levels between 1979 and 1986 was reported; however, 5 to 10 sites per day had ozone levels that exceeded the U.S. ozone standard. (The U.S. ozone standard is for peak events; hourly average ozone levels may exceed $120 \mathrm{ppb}$ on no more than one day per year.) In 1986, more than 75 million people in the United States lived in places that exceeded the national ozone standard (WRI and IIED 1988).

\subsubsection{Nitrogen Oxides}

In general, countries that measure $\mathrm{NO}_{\mathrm{x}}$ have had varying success in controlling it in urban air. The amount of data collected for Asian countries to date appears to be limited.

\subsection{DETERMINING ENVIRONMENTAL EXTERNALITY VALUES FOR ASIAN APPLICATIONS}

Before 1970, the externalities from electricity generation were largely unrecognized. This lack of attention to the consequences of environmental discharge imposed large costs on society by allowing a significant degradation of environmental quality. Thus, estimates of environmental externality values, although uncertain (with some values being very uncertain), are still considered quite useful. Nevertheless, many externalities continued to be left untreated, although the United States and other regulators (between 1970 and 1990) have attempted to internalize costs (Lave 1991).

Many values for environmental externalities have been proposed. A partial listing is presented in Table 4. The following discussion describes the work of Lave and briefly explains why his set of values was chosen as most appropriate for Asian conditions.

\subsubsection{Lave's Values}

\section{Basis for Lave's Values}

Lester Lave, a pioneer in the field and considered by many to be the "father of externalities" (Grahame 1992), has conducted research on the economics of energy, the economics of the environment, and environmental health and safety for more than two decades. In particular, his work on the effects of air pollution on health has been the basis for setting U.S. and state air quality standards (Lave 1991). 


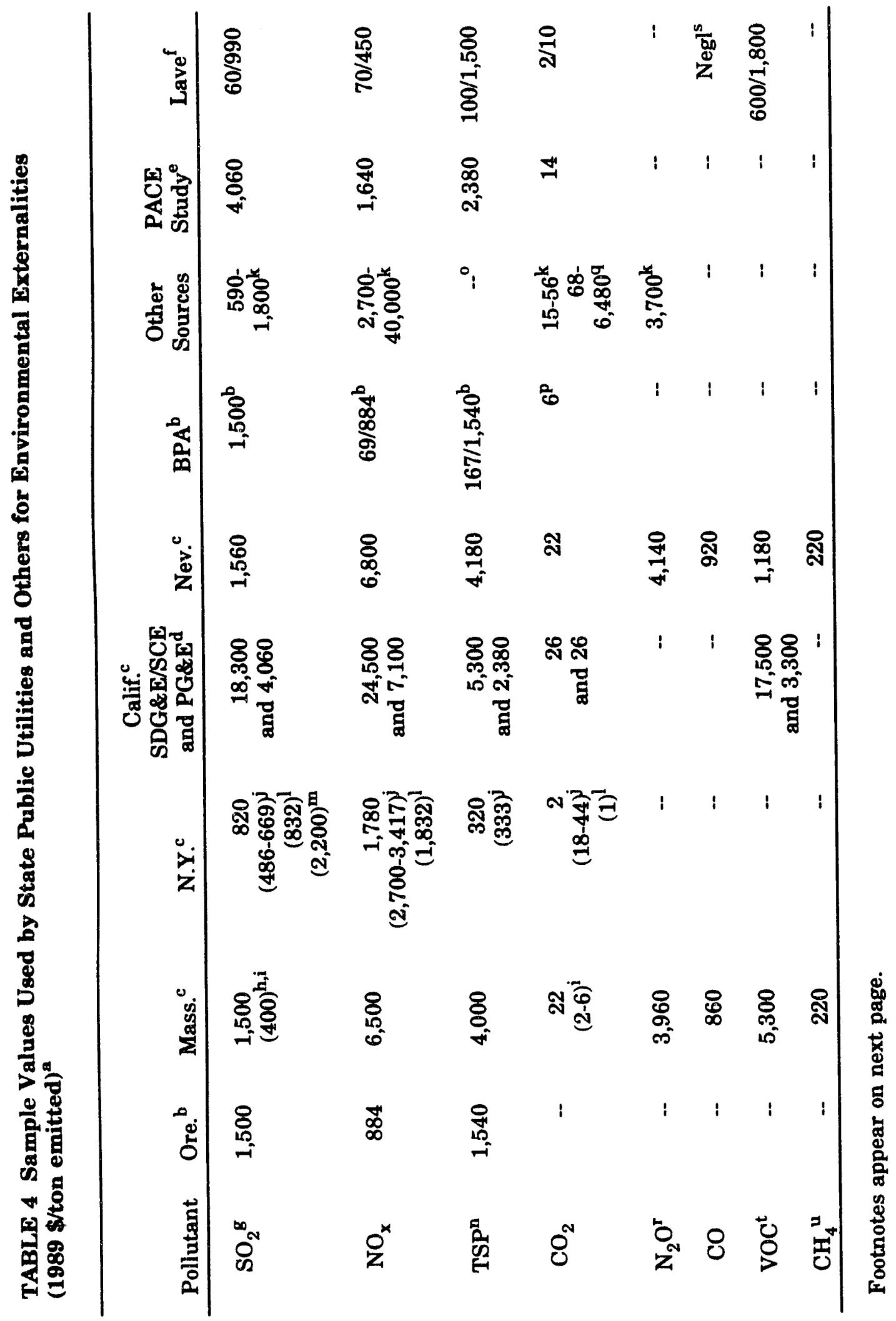




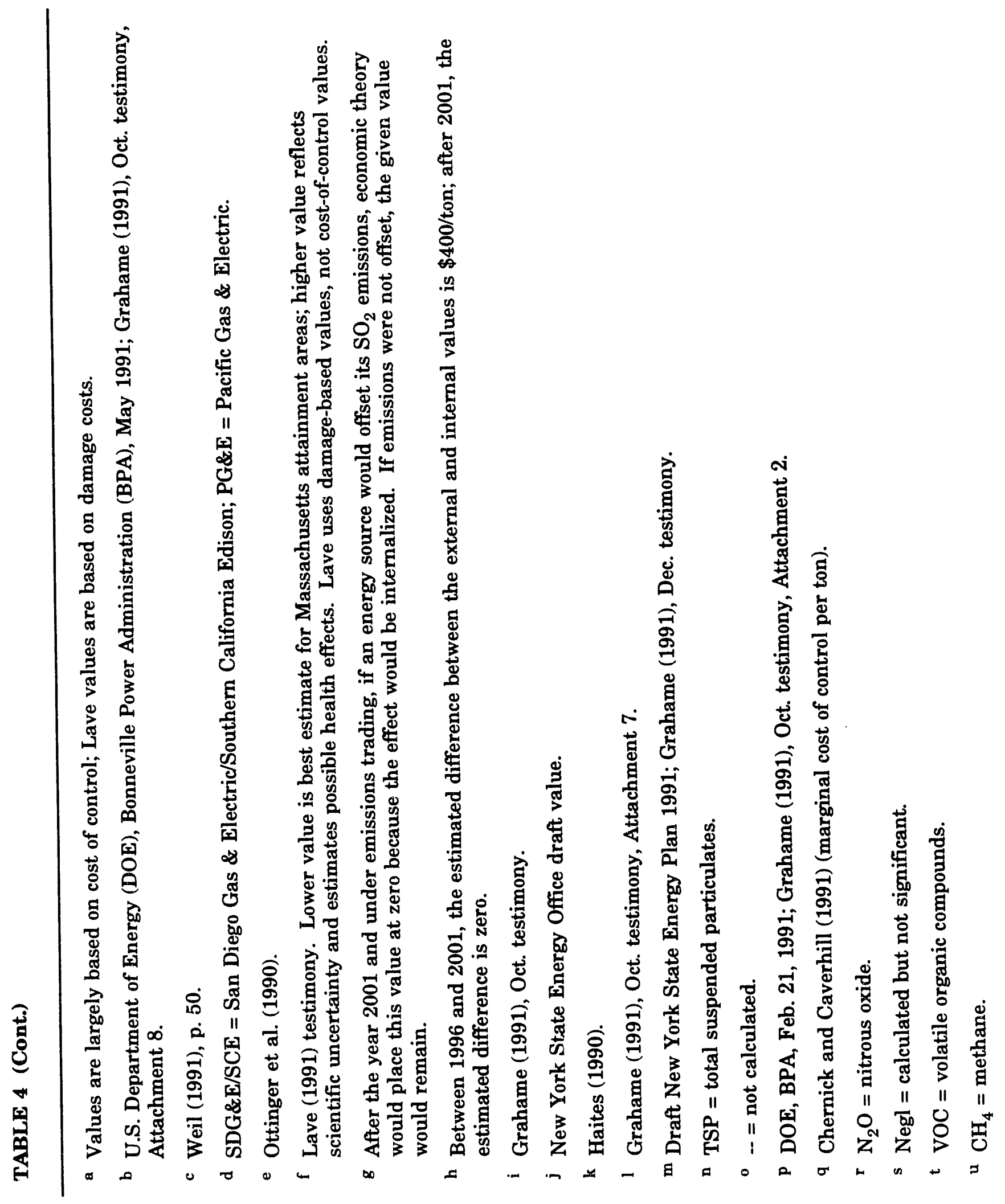


Lave has estimated externality values for emissions of air pollutants on the basis of the marginal benefit of abatement (i.e., the dollar benefit to society for abating emissions of the "criteria" air pollutants - particulates, $\mathrm{SO}_{2}, \mathrm{CO}, \mathrm{NO}_{2}$, ozone, and lead). To sum up his position, externality values should be chosen on the basis of the marginal benefit of abatement, not some ad hoc estimates of the marginal cost of abatement. Thus, he argues against the position held by Chernick and Caverhill among others - that the marginal cost of control can be a good surrogate for the marginal benefit of control. Jave further maintains that the externality values now being applied by state public utilities, which are primarily determined on the basis of the cost of control, may increase abatement expenditures and may even lower environmental quality in the process.

\section{Justification for Lave's Values}

In the 1970s, as already mentioned, Lave and Seskin found a close and persistent relationship between total suspended particulates (TSP) and mortality as well as a close relationship between the level of sulfates (in the TSP) and mortality on the basis of U.S. Environmental Protection Agency (EPA) data for 1960 through 1969. The implications of these relationships are that improvements in U.S. air quality over the past two decades have had a substantial health benefit. Moreover, they found that the relationship between air pollution and health was not statistically significant for areas that had already attained the U.S. primary air quality standards.

On the basis of his research, Lave believes that there are no significant adverse health effects from air pollution in attainment ${ }^{6}$ areas, only visibility and other adverse welfare impacts such as materials damage. However, to reflect the large amount of scientific uncertainty, specifically regarding health effects, Lave has also developed a set of higher values for externalities. These higher externality values reflect the assumption that the marginal benefit of abating pollution emissions in attainment areas (i.e., the benefit resulting frcm health effects) is $10 \%$ of the marginal benefit estimated for the relatively bad U.S. air pollution of the 1960s and 1970s. Nevertheless, even these higher externality values for attainment areas reflect his very conservative estimates overall.

Lave offers both his "best-guess" estimates (with no health-impact components) and his "higher" estimates (with allowance for the uncertainty that health impacts may be affected significantly) of the marginal benefits of abating (criteria) air pollutants in the state of Massachusetts, an area that is in attainment (except for ozone). He offers these values as a guide for those who establish pollution-abatement policies and choose technologies.

6 When an area is found to meet the U.S. NAAQS for a criteria pollutant (particulates, $\mathrm{SO}_{2}, \mathrm{CO}, \mathrm{NO}_{2}$, ozone, and airborne lead), it is determined to be in compliance or attainment. If its ambient air quality does not satisfy the standards, it is termed a nonattainment area. 


\subsubsection{U.S. Position on Values}

Presently, the U.S. Department of Energy does not support any damage-based estimates of environmental externality values, nor does it support any environmental externality values. Its position is to base such externality values on actual damage estimates, where and when such values become available (Grahame 1991).

Nevertheless, some state public utilities have taken positions (Table 4). They feel compelled to consider environmental externality values as an aid in evaluating the environmental effects of a particular decision, to account for the decision's benefits and impacts. Thus, they currently use environmental externality values in their planning and decision making. These state public utilities suggest that an appropriate application of environmental externality values can:

- Provide information that is better than that resulting from either ignoring the discharges or implementing a strictly command and control system and

- Give utilities specific dollar amounts to use in their resource procurement decisions.

Despite the positive aspects of applying these values, choosing an artificially high set of externality estimates may prove costly to society, in that it may lead to unwarranted emissions-control expenditures or, in a worst-case scenario, to the choice of the wrong technology, thereby increasing deleterious health effects and environmental damage (Lave 1991). Thus Lave punts out that his estimates are more conservative than those currently being used by the state public utilities and may be more appropriate.

\subsubsection{Application of Lave's Values to Asian Situation}

Which values should be used in any Asian application? A comparison of the Lave estimates with others (Table 4) shows that the Lave values are lower than most (i.e., they are conservative estimates of the value of environmental externalities to be used in attainment areas). Use of such values in evaluating clean coal technologies (CCTs) will thus reflect the minimal benefits attributable to these technologies. Despite this fact, as a consequence of the above considerations (including the fact that the Asian region can generally be considered to be a nonattainment area where significant health impacts can be expected), this report uses the higher, but still conservative, Lave externality values (with allowance for health impacts) in the analysis of CCTs in Asian applications. Using such 
values in evaluating CCTs results in outcomes that reflect the minimum benefits attributable to these technologies. ${ }^{7}$

To emphasize the choice of environmental externality values, the higher Lave values are used because:

- Many researchers in the field (and the authors of this report) think that direct damage estimates reflect the actual activity better than do indirect proxy values such as those put forth by Chernick and Caverhill (1991).

- Lave has a wealth of experience in the fields of health risk assessment and environmental externalities and has shown excellent judgment over the years (Grahame 1992).

- Although the Lave environmental externality values are very conservative estimates of health-related damage, the findings will err on the conservative side. In other words, the environmental benefits to be obtained by considering environmental externalities will actually be greater than those reported.

7 To consider the concept of environmental externalities more rigorously, one may need to consider the net system impacts resulting from the addition of new units. What this suggestion means is that "equal amounts of capacity will result in different net emissions because the capacity types have different capacity factors and, therefore, (will) displace different amounts of existing (relatively dirty) capacity" (Grahame 1992). According to Andrews (1991), "Continued operation of existing power plants and the dynamic(s) of new supply technology development [may provide] many costeffective emissions reduction opportunities. ... A A superior approach is to take a systemic perspective on the emissions reduction challenge, and compare complete resource portfolios rather than options at the margin." 


\section{APPLYING ENVIRONMENTAL EXTERNALITIES TO ASIAN COUNTRIES}

Extensive research and development (R\&D) is underway to improve coal-based technologies so that the use of coal, a vast energy resource, can be expanded while strict environmental siandards are maintained. Because a whole slate of technological options has been developed, decision makers have a greater latitude in balancing the needs of a growing population, desired economic expansion, environmental concerns, and costs. The scope of ongoing R\&D includes improved coal cleaning processes, more efficient combustion technologies, and improved flue-gas cleanup systems that will control $\mathrm{SO}_{2}, \mathrm{NO}_{\mathrm{x}}$, and particulate emissions without producing large quantities of solid waste. These technologies under development are applicable to a variety of facilities (including both refurbished and new facilities and industrial and electric utility plants) and a wide range of coals.

In the United States, R\&D on CCTs - a new generation of advanced, coal-based technologies - continues, with numerous jointly funded demonstration projects. The U.S. CCT Demonstration Program is designed to take some of the most promising advanced coal-based technologies and move them into the commercial marketplace over the next decade. These advanced technologies are expected to be environmentally cleaner and, in many cases, more efficient and less costly than conventional coal processes. The widespread interest in coal technologies and utilization is evidenced by the fact that many foreign countries and companies also have large coal R\&D programs (Guziel et al. 1991).

\subsection{SCENARIO ASSUMPTIONS}

The method developed in this study is being applied to new, coal-based, electricity-generating plants sited in Indonesia, Thailand, and Taiwan. The specific objective is to compare plants that might use advanced technologies and that could achieve high levels of emissions control with a reference-case plant that is fired by pulverized coal (PC) and that uses no flue-gas desulfurization (FGD) treatment other than a moderate level of particulate control. An examination of the requirements for each country indicated that (1) a new plant in Indonesia is likely to have a generating capacity of approximately $600 \mathrm{MW}$, (2) Thailand is more likely to build a plant of about 300-MW capacity, and (3) Taiwan will probably build units with capacities of $550 \mathrm{MW}$, in most cases, with a few possibly at $750 \mathrm{MW}$. Hence, these plant sizes were chosen for this analysis.

In Taiwan, all new coal-fired power plants are expected to comply with government regulations on $\mathrm{SO}_{2}, \mathrm{NO}_{\mathrm{x}}$, and particulate emissions. Taipower reports that all of its proposed coal-fired units will be equipped with modern flue-gas emission-reduction devices (e.g., electrostatic precipitators, baghouse filters, FGD units, and deNO $\mathrm{x}_{\mathbf{x}}$ devices) to reduce the pollutants to their minimum practical levels (Chang 1989). 
New requirements for coal-based electricity-generating units in the sizes needed create an opportunity for several CCTs currently under demonstration in the United States. Options to be considered include:

- A PC-fired plant with no $\mathrm{SO}_{2}$-emissions control and a moderate level of particulate control - the reference case. (This option is not under consideration for use in Taiwan, but it can serve as a reference case to demonstrate the effectiveness of emissions control capabilities available in CCTs);

- A PC-fired plant with $\mathrm{SO}_{2}$-emissions control and a higher level of particulate control - PC/FGD;

- An atmospheric fluidized-bed combustion plant - AFBC;

- A pressurized fluidized-bed combustion plant - PFBC; and

- An integrated coal gasification combined-cycle plant - IGCC.

Estimates of the reduction levels and emission rates for air pollutants from these generic coal technologies are presented in Table 5 . These values are considered representative of those for a family of variations within each technology and serve as the base-case estimates in this analysis.

The values for $\mathrm{SO}_{2}$ and particulate control given in Table 5 do not necessarily represent the full capabilities of the advanced technologies. Instead, they are intended to represent improvements over the reference PC-fired plant assumed for Asian applications. Values for $\mathrm{CO}_{2}$ emissions are based on a release rate of $205 \mathrm{lb} / 10^{6} \mathrm{Btu}$ of heat input, adjusted by the efficiency of the technology and an assumed amount of limestone required for $\mathrm{SO}_{2}$ control.

TABLE 5 Base-Case Emission Rates and Reduction Levels, by Technology

\begin{tabular}{lrrrrr}
\hline & PC with No & PC with & & & \\
\multicolumn{1}{c}{ Pollutant } & $\mathrm{SO}_{2}$ Control & $\mathrm{SO}_{2}$ Control & AFBC & PFBC & IGCC \\
\hline $\mathrm{SO}_{2}(\%)$ & No control & 80 & 80 & 90 & 95 \\
$\mathrm{NO}_{\mathrm{X}}(\mathrm{ppm})$ & 800 & 400 & 150 & 150 & 150 \\
$\mathrm{TSP}(\%)$ & 80 & 90 & 90 & 95 & 99.99 \\
$\mathrm{CO}_{2}(\mathrm{lb} / \mathrm{kWh})$ & 2.0 & 2.1 & 2.2 & 1.9 & 1.9 \\
$\mathrm{~N}_{2} \mathrm{O}(\mathrm{ppm})$ & 1 & 1 & 1 & 1 & 1 \\
$\mathrm{CO}(\mathrm{ppm})$ & 120 & 120 & 200 & 170 & 5 \\
\hline
\end{tabular}


Several coals are examined in this analysis. These coals reflect the range of possible fuel sources for these specific applications. For Indonesia and Thailand, two indigenous coals and two imported coals (an Australian coal and a U.S. Appalachian coal) are considered for each country. Relevant coal characteristics are presented in Table 6.

Of the total of 19 million metric tons of coal used in Taiwan in 1990, only about 3\% was from indigenous sources. The remaining $97 \%$ was imported from Australia, th? United States, Canada, South Africa, and Indonesia. Approximately half of this imported coal was from Australia; the other half was predominately from the United States and South Africa. Thus, for purposes of the analyses presented here, it was assumed that the new coal-based plants will be fueled with coals imported from Australia, the United States, or South Africa (Szpunar and Gillette 1990; Chuang 1991).

Table 7 presents selected characteristics of coals that could be imported from these countries. These characteristics represent raw coal and are not necessarily the precise characteristics of the coal that would actually be received at the plant site. The coals include both a high-sulfur and a high-ash coal from the United States, which are not necessarily the most commonly exported U.S. coals. Although both U.S. coals could easily be beneficiated to remove substantial fractions of sulfur and ash, they are presented here to serve as an illustration of the enhanced environmental qualities of CCTs. Of course, other coals could also be imported to Taiwan, but these coals were selected to illustrate the points of these analyses.

The original scope of this project included a consideration of all types of emissions (i.e., airborne and waterborne) and residuals (e.g., those found in soil as a result of land use) and of the entire fuel cycle (i.e., mining, transportation, power generation, and waste

TABLE 6 Representative Coal Quality Characteristics for Indonesia and Thailand.

\begin{tabular}{|c|c|c|c|c|c|c|}
\hline \multirow[b]{2}{*}{ Source/Name } & \multirow[b]{2}{*}{ Rank } & \multicolumn{2}{|c|}{ Calorific Value } & \multicolumn{3}{|c|}{ Content (\%) } \\
\hline & & Btu/lb & kcal/kg & Moisture & Ash & Sulfur \\
\hline $\begin{array}{l}\text { Indonesia/ } \\
\text { Ombilin }\end{array}$ & Bituminous & 13,250 & 7,360 & 4.1 & 5.6 & 1.5 \\
\hline $\begin{array}{l}\text { Indonesial } \\
\text { Pt. Arutmin }\end{array}$ & Bituminous & 11,160 & 6,300 & 4.0 & 15.0 & 0.7 \\
\hline $\begin{array}{l}\text { Thailand/ } \\
\text { Mae Moh }\end{array}$ & Lignite & 4,950 & 2,750 & 34.0 & 20.2 & 0.5 \\
\hline $\begin{array}{l}\text { Thailand/ } \\
\text { Krabi }\end{array}$ & Lignite & 4,150 & 2,310 & 30.0 & 26.0 & 3.5 \\
\hline $\begin{array}{l}\text { Australia/New } \\
\text { South Wales }\end{array}$ & Bituminous & 12,240 & 6,800 & 3.0 & 13.5 & 0.5 \\
\hline $\begin{array}{l}\text { United States/ } \\
\text { Upper Freeport }\end{array}$ & Bituminous & 9,750 & 5,420 & 4.8 & 30.2 & 1.8 \\
\hline
\end{tabular}


TABLE 7 Representative Coal Quality Characteristics for Taiwan

\begin{tabular}{lccccccc}
\hline & \multicolumn{2}{c}{ Calorific Value } & & \multicolumn{3}{c}{ Content (\%) } \\
\cline { 2 - 3 } \multicolumn{1}{c}{ Source/Name } & Btu/lb & kcal/kg & & Moisture & Ash & Sulfur \\
\hline Australia/Hunter Valley & 11,510 & 6,390 & & 9.0 & 12.7 & 0.5 \\
Australia/Ulan & 10,880 & 6,050 & & NA & 16.3 & 0.7 \\
South Africa/Ermelo & 11,240 & 6,240 & & NA & 12.6 & 1.0 \\
South Africa/Witbank & 10,880 & 6,050 & & NA & 15.1 & 1.0 \\
United States/Upper Freeport & 9,750 & 5,420 & & 4.8 & 30.2 & 1.8 \\
United States/llinois No. 6 & 10,270 & 5,710 & & 9.5 & 16.8 & 4.2 \\
\hline
\end{tabular}

all coals are ranked as bituminous.

b $\mathrm{NA}=$ not available.

disposal). Ultimately, however, the scope was narrowed to cover only airborne emissions resulting from the power-generation phase of the fuel cycle. This action was taken for the following reasons:

- The data on externalities for areas other than air emissions are very limited. Although some data on land and water usage do exist, the data are in cents per kilowatt-hour, and there is not enough information to translate these estimates into other units of measure or to show differences among technologies using the same fuel. Because the plants using advanced coal-based technologies are compared with a plant of equal capacity, there is no difference in the externality costs relative to the various technologies.

- Some of the other externality costs are proportional to the quantity of coal being mined and burned. Although the plants using advanced, coalbased technologies are generally more efficient than the reference-case plant, the differences are relatively small. Because there is such a significant uncertainty in externality values, differences in externality costs attributable to the differing quantities of coal being mined and transported were omitted from consideration. As a result, the reductions in externality costs that would be provided by the more efficient, coal-based technologies are underestimated in these analyses - a conservative position.

General locations in Indonesia, Thailand, and Taiwan are considered for these potential facilities; site-specific locations are not considered. As discussed earlier, however, there was general agreement that the externality values used in any application should be considered relative to the ambient air quality at the specific location. Therefore, because 
much of Indonesia, Thailand, and Taiwan is not in attainment with WHO air quality standards, these analysis reflect their nonattainment conditions.

\subsection{METHOD DEVELOPED}

Traditional methods for determining the costs of electricity production involve techniques for annualizing capital expenses, incorporating O\&M costs, and calculating fuel costs. These costs form the basis for establishing the price of electricity to consumers. Utilities have acknowledged concerns related to environmental issues by ensuring compliance as dictated by regulators, by incorporating the additional costs of compliance into the cost of electricity, and by conducting some evaluation of the impacts or consequences of the emissions or residuals.

By combining the economic value of environmental impacts with the quantity of electricity produced per unit of emission, an environmental cost of electricity production can be determined. This cost can be expressed in the same terms as are the more traditional costs (e.g., U.S. cents per kilowatt-hour) and can thus be combined with the traditional costs. It can also be directly compared with the traditional costs to illustrate the relative magnitudes of each type of cost. This externality cost can be combined with traditional costs to be used as a decision tool in least-cost methodologies to optimize the selection and operation of generating technologies. It can also be used in methodologies that calculate lifecycle costs in which both generating and environmental costs can be incorporated.

For these analyses, a model was developed to estimate the traditional cost of electricity production for conditions representative of those in Indonesia, Thailand, and Taiwan. Externality costs were estimated through the use of the emission rates (or control levels) for the individual technologies and the externality values. These costs were added to yield a total cost for each option.

A figure of merit was developed to illustrate the benefit-to-cost ratio for each advanced technology option relative to that of the reference case. This figure of merit is equal to the benefit of reduced atmospheric emissions divided by the increase in the traditional cost of electricity production. A benefit-to-cost ratio of less than 1.0 means that the benefits are less than the additional production costs, while a ratio of more than 1.0 means that the benefits exceed the additional costs. A ratio of 1.0 means that the benefits of reduced atmospheric emissions exactly offset the additional cost of electricity production.

\subsection{OTHER STUDY ASSUMPTIONS}

In addition to the technology characteristic assumptions listed in Table 5, several economic and technical assumptions were made to allow quantitative assessments of the emissions control costs and benefits of the CCTs. An annual discount rate of $5 \%$ was selected as being representative of these applications. All technologies were considered to operate as baseload plants, with capacity factors of $70 \%$ over a 30 -year lifetime. As already stated, an 
evaluation indicated that a $600-\mathrm{MW}$ facility would represent new power plant requirements in indonesia, a 300-MW plant would be more typical of new construction in Thailand, and 550-MW coal-fireci units are anticipated for Taiwan. The analyses herein were performed in terms of constant U.S. dollars. Basic fuel costs ranged from U.S. $\$ 6.30$ to $\$ 8.30$ per million kilocalories ( $\$ 1.60$ to $\$ 2.10$ per million Btu).

For purposes of these analyses, it was assumed that all of the additional costs of the advanced technologies, as compared with those of the reference PC plant, are attributable to environmental controls. In reality, some of these additional costs could result from the desire to make the advanced technologies more reliable and more fuel flexible. By assigning all additional costs to environmental control, the results of the analyses underestimate (i.e., are a conservative estimate of) the ratio of benefits to costs. Thus, the advanced technologies should provide, in practice, an environmental-benefit/environmental-control-cost ratio as least as high as the values presented in this report, if not higher.

As noted earlier, a wide range of values has been suggested for the various environmental externalities to be employed. This range reflects the uncertainty associated with a number of factors, including the effect of dose-response relationships on human health, the contribution that the relationships of various pollutants makes to impacts such as acid rain and global climate change, and the economic value of each of these responses and impacts. The environmental externality values selected for this analysis are the higher of Lave's conservative externality values, which are neither the highest nor the lowest values that could be considered. These values, however, do represent the lowest environmental externality values available that include health effects. Thus, the use of these values also tends to result in a benefit-to-cost ratio that is conservative (lower) than those that would result from the use of other externality values that incorporate health effects.

The level of ambient air quality was an important consideration in selecting which environmental externality values to use. The base case represents a situation in which an Asian power plant is located in an area that is not in compliance with WHO air quality standards - the situation judged to be generally applicable in Indonesia, Thailand, and Taiwan. (Refer to Section 5.1 and Tables 2 and 3 for detailed information about air quality in these Asian countries.)

\subsection{STUDY RESULTS}

The numerical results of this analysis include values for the traditional cost of electricity production (capital, O\&M, and fuel) and for the cost of environmental externalities. As noted earlier, a ratio of the incremental benefits due to the reduction in emissions divided by the incremental cost in the traditional cost of electricity production is used as a figure of merit for these technologies.

Results from these analyses are shown in Tables 8 and 9 . In every case, the results demonstrate a benefit-to-cost ratio that is greater than 1.0. In other words, over the variety 
TABLE 8 Ratio of Reduced Cost of Environmental Externalities to Increased Cost of Electricity Production in Indonesia and Thailand ${ }^{a}$

\begin{tabular}{|c|c|c|c|c|c|c|c|}
\hline Country & Technology & $\begin{array}{l}\text { Indonesia } \\
\text { Ombilin } \\
\text { Bituminous }\end{array}$ & $\begin{array}{c}\text { Indonesia/ } \\
\text { Pt. } \\
\text { Arutmin } \\
\text { Bituminous }\end{array}$ & $\begin{array}{l}\text { Thailand/ } \\
\text { Mae Moh } \\
\text { Lignite }\end{array}$ & $\begin{array}{c}\text { Thailand/ } \\
\text { Krabi } \\
\text { Lignite }\end{array}$ & $\begin{array}{c}\text { Australia/ } \\
\text { New South } \\
\text { Wales } \\
\text { Bituminous }\end{array}$ & $\begin{array}{c}\text { U.S. } \\
\text { Upper } \\
\text { Freeport } \\
\text { Bituminous }\end{array}$ \\
\hline \multirow[t]{4}{*}{ Indonesia } & PC/FGD & 1.5 & 2.1 &..$^{b}$ & .. & 1.7 & 4.7 \\
\hline & AFBC & 1.5 & 1.8 & -- & -- & 1.4 & 3.9 \\
\hline & PFBC & 2.7 & 3.9 & -. & - & 3.3 & 9.5 \\
\hline & IGCC & 3.0 & 5.2 & -- & -. & 4.1 & 11.9 \\
\hline \multirow[t]{4}{*}{ Thailand } & PC/FGD & .. & -. & 5.5 & 10.7 & 1.4 & 3.9 \\
\hline & AFBC & -. & -. & 6.2 & 9.4 & 1.6 & 3.9 \\
\hline & PFBC & -. & -. & 11.1 & 21.0 & 3.1 & 8.7 \\
\hline & IGCC & -. & -. & 38.9 & 69.6 & 28.2 & 127.3 \\
\hline $\begin{array}{l}\text { Ratios } \\
\text { Lave. }\end{array}$ & ased on th & her of the $c$ & rvative he & ased env & ntal exte & ty values es & hed by \\
\hline b $\quad-=$ not & licable. & & & & & & \\
\hline
\end{tabular}

TABLE 9 Ratio of Reduced Cost of Environmental Externalities to Increased Cost of Electricity Production in Taiwan

\begin{tabular}{lcccccc}
\hline & $\begin{array}{c}\text { Australia/ } \\
\text { Hunter } \\
\text { Valley }\end{array}$ & $\begin{array}{c}\text { Australia/ } \\
\text { Ulan }\end{array}$ & $\begin{array}{c}\text { South } \\
\text { Africal } \\
\text { Ermelo }\end{array}$ & $\begin{array}{c}\text { South } \\
\text { Africal } \\
\text { Witbank }\end{array}$ & $\begin{array}{c}\text { U.S./ } \\
\text { Upper } \\
\text { Freeport }\end{array}$ & $\begin{array}{c}\text { U.S./ } \\
\text { Illinois } \\
\text { No. 6 }\end{array}$ \\
\hline PC/FGD & 1.6 & 2.1 & 1.9 & 2.1 & 4.4 & 4.4 \\
AFBC & 1.6 & 2.1 & 1.9 & 2.2 & 4.2 & 4.7 \\
PFBC & 1.8 & 2.4 & 2.1 & 2.4 & 5.0 & 4.7 \\
IGCC & 2.6 & 3.4 & 2.9 & 3.4 & 7.2 & 6.1 \\
\hline
\end{tabular}

a All coals are ranked bituminous.

of technology applications and coal ranks and types considered, the value of the reduction in atmospheric emissions is far greater than the additional cost that may be incurred in attaining the higher levels of emissions control.

The benefit-to-cost ratio is generally in the range of $z$ to 10 , with a maximum value of 127 estimated for the IGCC application in Thailand, in which an easily burned U.S. Appalachian coal (Upper Freeport) is the fuel. Table 6 shows that this coal has the highest ash content of all coals considered and one of the highest sulfur contents, despite being one of the easiest to burn. The highest ratios were found for IGCC technology, which has high levels of particulate and sulfur control, but whose costs are comparable to those of the other technologies. As previously mentioned, the performance parameters used in these analyses do not necessarily represent the full capabilities of the technologies. Higher benefit- 
to-cost ratios are expected to be exhibited for coals with higher ash and sulfur contents, because greater reductions in emissions of atmospheric pollutants can be attained.

A more detailed examination of these results provides some additional insight into their significance. The traditional cosi of producing electricity in Indonesia in an IGCC plant burning Upper-Freeport-quality coal is estimated at approximately $4.1 \notin / \mathrm{kWh}$ (U.S. currency). The corresponding cost for the reference-case PC unit is approximately $3.7 \varnothing / \mathrm{kWh}$. However, the cost of the environmental externalities due to air emissions from the IGCS is approximately $1.0 \% / \mathrm{kWh}$, while the emissions from the reference facility have a cost of about $5.8 \mathrm{c} / \mathrm{kWh}$. (These figures yield the benefit-to-cost ratio of 11.9 listed in Table 8 [(benefit of $5.8-1.0) /(\operatorname{cost}$ of $4.1-3.7)]$.) Thus, when the 600-MW plant operates for a year at a capacity factor of $70 \%$, the additional cost of electricity production is less than $\$ 15$ million. However, the reduction in atmospheric emissions realized by using the IGCC technology rather than the reference-case technology reduces environmental externality costs by more than $\$ 176$ million per year.

A similar breakdown of the costs of the IGCC in Thailand, where plant capacity is $300 \mathrm{MW}$, shows that the traditional costs are nearly equal to those of the IGCC plant slightly more than $4.0 \mathrm{f} / \mathrm{kWh}$ - and that the costs of the reference-case plant are slightly less than that amount. However, the externality costs are 1.0 and $5.8 \% / \mathrm{kWh}$ for the IGCC and reference plant, respectively. (These figures lead to the benefit-to-sost ratio of 127 listed in Table 8 [(benefit of $5.8-1.0)$ (cost of about 4.0 - about 4.0)].) Thus, by spending less than $\$ 0.7$ million per year in additional electricity production costs, savings of more than $\$ 88$ million per year in externality costs can be realized.

The traditional cost of producing electricity in Taiwan, with IGCC technology and U.S. Upper Freeport coal as the fuel, is estimated at approximately $4.4 \mathrm{c} / \mathrm{kWh}$. The corresponding cost for the reference-case PC-fired unit is approximately $3.8 € / \mathrm{kWh}$. However, the cost of the environmental externalities that result from air emissions from the IGCC is approximately $5.5 \notin / \mathrm{kWh}$, while the emissions from the reference plant have a cost of about $9.6 \mathrm{~g} / \mathrm{kWh}$. Thus, when the 550-MW plant operates for a year at a capacity factor of $70 \%$, it costs about $\$ 22.5$ million more to produce electricity by using IGCC technology than by using the reference technology. However, the reduction in atmospheric emissions realized by using the IGCC rather than the reference technology reduces environmental externality costs by $\$ 162$ million.

A further breakdown of the environmental externality costs shows the various components of these costs and the value of controlling the individual pollutants. Under the assumptions of this analysis, the total environmental externality cost consists principally of the costs for controlling $\mathrm{SO}_{2}, \mathrm{NO}_{\mathbf{x}}, \mathrm{CO}_{2}$, and, for the reference-case $\mathrm{PC}$ plant, particulates. The total externality cost for the reference-case PC plant burning Krabi lignite consists of $4.15 \notin$ for controlling $\mathrm{SO}_{2}, 0.27 \notin$ for controlling $\mathrm{NO}_{\mathrm{x}}, 1.02 \notin$ for controlling $\mathrm{CO}_{2}$, and $7.48 \notin$ for controlling particulates, for a total of $12.92 \phi / \mathrm{kWh}$. Burning the same lignite in an IGCC unit reduces these costs to $0.21 \phi$ for controlling $\mathrm{SO}_{2}, 0.05 \phi$ for controlling $\mathrm{NO}_{\mathrm{x}}, 1.02 \phi$ for controlling $\mathrm{CO}_{2}$, and zero for controlling particulates, for a total of $1.28 \notin / \mathrm{kWh}$. The values, 
of course, depend upon the fuel being used, with $\mathrm{SO}_{2}$ and particulate control costs being strongly dependent on the fuel. The advanced technologies provide only small reductions in the $\mathrm{CO}_{2}$ control costs because each technology uses the same carbon-based fuel.

As indicated in Tables 8 and 9, the estimated figures of merit for the other cases considered are lower than those in these examples, but all ratios are greater than 1.0, thus showing that an investment in U.S. CCTs would be more than repaid by reductions in costs from air pollution from the reference plant burning the same coal.

\subsection{STUDY SENSITIVITIES}

The environmental externality values involve considerable uncertainty with respect to the state of the science (e.g., atmospheric dispersion and health effects) and the selected economic values (e.g., the dollar value of a health impact or of visibility impairment). Nevertheless, sensitivity analyses were performed on several parameters, including capital and operating costs, values of environmental externalities, and base-case emission rates and levels of emissions control. Although the individual costs and benefits changed (in some cases, the estimated benefit-to-cost ratio became less than 1.0 ), the basic conclusions remain the same.

- Significant environmental benefits are likely to accrue when CCTs are used, and

- The value of these benefits will generally be much greater than the incremental cost incurred from reducing emissions.

Therefore, environmental externality values can be used as demonstrated here to quantitatively estimate the benefits to be derived, so that they can be compared with the cost of electricity production. 


\section{OBSERVATIONS}

A number of observations about the analyses described herein are appropriate. Several of them are briefly summarized below.

- The concept of environmental externalities has recently received greater attention, after a relatively long hiatus of about 10 years. Recent advances in basic knowledge about, and in modeling capabilities dealing with, dose-response characteristics, atmospheric dispersion, medical treatment, and other factors have led to a better understanding of the impacts of pollutants. The economic value of these impacts is an area under constant investigation, and additional information in this regard is being accumulated and evaluated.

- As demonstrated in the methodology development and its application as described in this report, environmental externality costs can be expressed in a framework that is consistent with traditional methods of determining the cost of electricity production. Such a framework allows one to compare the component costs and develop a figure of merit that allows for a cost-benefit comparison, which can be used to evaluate the tradeoffs being made. The methodology also allows traditional and externality costs to be combined in a way that is appropriate for leastcost planning and for determining life-cycle costs.

- Under base-case assumptions, these analyses demonstrated that CCTs provided economic benefits (resulting from reductions in atmospheric emissions) that were significantly greater than the incremental costs incurred to attain these reductions. The benefits were achieved even though very conservative assumptions were used in all phases of the analyses. Assumptions were made about the value of each externality and the type of emissions (i.e., only atmospheric); also, all the incremental costs of the advanced technologies were assumed to result from the control of atmospheric emissions. Less conservative assumptions would result in estimates having greater benefit-to-cost ratios than those presented here. 


\section{REFERENCES}

Amaral, D., 1988, "Including Uncertainty in Assessments of Sulfur Oxide Health Risks," Journal of Air Pollution Control Association 38(4):399-405, April.

Black, S.C., and F. Niehaus, 1980, "Comparison of Risks and Benefits among Different Energy Systems," in Interactions of Energy and Climate, W. Bach et al. (editors), D. Reidel Publishing Co., Dordrecht, The Netherlands, pp. 421-436.

Bernow, S., et al., 1991, "Fuel-Cost Dispatch: Incorporating Environmental Externalities in Electric System Operation," Electricity Journal 4(2):20-23, March.

Boras, K., et al., 1990, Considering Social Costs in Utility Decision Making: Alternative Approaches and Implementation, Pacific Gas and Electric Company, San Francisco, Calif., Nov. 1.

Brown, C., 1980, "Equalizing Differences in the Labor Market," Quarterly Journal of Economics 94:113-134, Feb.

Chang, S.-M., 1989, "Future Coal-Fired Generation Plan of Taiwan Power Company," presented at the Asia-Pacific Coal Technology Conference, sponsored by the East-West Center, Resource Systems Institute, and the U.S. Department of Energy, Office of Fossil Energy, held in Honolulu, Hawaii, on Nov. 15-16.

Chernick, P., and E. Caverhill, 1991, "Methods of Valuing Environmental Externalities," Electricity Journal 4(2):46-53, March.

Chow, J.C., et al., 1983, "Air Pollution in the Republic of China (Taiwan)," Journal of the Air Pollution Control Association 33(8):768-770, Aug.

Chuang, C.-Y., and S.-H. Shen, 1986, "Air Pollution in Taiwan," in vol. 4 of proceedings of the Seventh World Clean Air Congress, H.F. Hartman (editor), sponsored by the Clean Air Society of Australia and New Zealand, pp. 386-393.

Chuang, S.-M., 1991, "Coal and Environmental Regulation for Taiwan Area," presented at Coal and the Environment: Asia 2010 Conference, sponsored by the East-West Center, Energy Program, and the U.S. Department of Energy, Office of Fossil Energy, held in Honolulu, Hawaii, on July 11-12.

Crocker, T.D., et al., 1979, "Methods Development for Assessing Air Pollution Control Benefits," in vol. 1 of Experiments in the Economics of Epidemiology, U.S. Environmental Protection Agency, Washington, D.C.

Daly, H., 1990, "The Ecological Economics of Sustainability," presented at conference sponsored by the International Society for Ecological Economists, held on May 21-23, published by The World Bank, Washington, D.C. 
Easterling, J.B., et al., 1990, "Social Issues and Challenges in the Disposal of Nuclear Waste," in vol. 2 of High Level Radioactive Waste Management, proceedings of the International Topical Meeting, sponsored by the American Society of Civil Engineers and the American Nuclear Society, held in Las Vegas, Nev., on April 8-12.

ECO Northwest, 1987, Generic Coal Study: Quantification and Valuation of Environmental Impacts, prepared by ECO Northwest, Portland, Ore., for Bonneville Power Administration, Portland, Ore.

EPA, 1991, National Air Quality and Emissions Trends Report, 1989, report EPA-450/4-91003, U.S. Environmental Protection Agency, Office of Air Quality, Planning and Standards, Technical Support Division, Research Triangle Park, N.C., Feb.

Finnell, J., et al., 1990, Evaluating Externalities Related to the Energy Sector, prepared by Meridian Corp. for PT Resource Development Consultants (REDECON) as an attachment to the Energy Pricing and Policy Study (EPPS), Aug. 1.

Freeman, A.M., 1985, "Methods for Assessing the Benefits of Environmental Programs," in vol. 1 of Handbook of Natural Resource and Energy Economics, A.V. Kneese and J.L. Sweeney (editors), Elsevier Science Publishers, Amsterdam, The Netherlands, pp. 223-270.

Freeman, A.M., 1982, Air and Water Pollution Control: A Benefit-Cost Assessment, John Wiley \& Sons, Inc., New York, N.Y.

Freeman, A.M., 1979, The Benefits of Environmental Improvement: Theory and Practice, Resources for the Future, Inc., Washington, D.C., published by Johns Hopkins Press, Baltimore, Md.

French, H., 1990, "You Are What You Breathe," Worldwatch 3(3):27-34, May-June.

Fujita, S.-I., et al., 1991, "Preliminary Inventory of Sulfur Dioxide Emissions in East Asia," Atmospheric Environment 25A(7):1409-1411.

Grahame, T.J., 1992, personal communication, U.S. Department of Energy, Office of Fossil Energy, Washington, D.C.

Grahame, T.J., 1991, testimony by Grahame, U.S. Department of Energy, Office of Fossil Energy, before the Commonwealth of Massachusetts Department of Public Utilities, Boston, Mass., Oct. 4 and Dec. 1.

Guziel, K.A., et al., 1991, Clean Coal Technologies - An International Seminar: Seminar Evaluation and Identification of Potential CCT Markets, report ANL/EAIS/TM-62, Argonne National Laboratory, Argonne, Ill., July. 
Haites, E.F., 1990, "Introduction to the Use of Social Costs in Utility Planning and Regulation," in proceedings of National Conference on Environmental Externalities, sponsored by National Association of Regulatory Utility Commissioners, held in Jackson Hole, Wyo., on Oct. 1-3.

Heintz, H.T., et al., 1976, National Damages of Air and Water Pollution, report prepared by Enviro Control, Inc., Rockville, Md., for U.S. Environmental Protection Agency.

Hohmeyer, O., 1988, Social Costs of Energy Consumption - Externalities of Electricity Generation in the Federal Republic of Germany, Springer-Verlag, Berlin, West Germany.

Intarapravich, D., 1991, "Coal and the Environment in Thailand," presented at Coal and the Environment: Asia 2010 Conference, sponsored by the East-West Center, Energy Program, and the U.S. Department of Energy, Office of Fossil Energy, held in Honolulu, Hawaii, on July 11-12.

Jacobson, B., 1984, "The Role of Air Pollution and Other Factors in Local Variations in General Mortality and Cancer Mortality," Archives of Environmental Health 39(4):306-313, Aug.

Jones, D.E., and P. Hanser, 1991, Environmental Externalities: An Overview of Theory and Practice, report CU/EN-7294, Electric Power Research Institute, Palo Alto, Calif., May.

Joskow, P.L., 1991, "Dealing with Environmental Externalities: Let's Do It Right!" prepared for the Harvard Northeast Electric Utility Executive Conference, held in Killington, Vt., on Oct. 17-18.

Kowalczyk, G.S., et al., 1988, "Emissions of Air Toxics from a Coal-Fired Power Plant: Evaluating the Trade-Offs between Public Health Risks and Emission Control Costs," in proceedings of the 81st annual meeting of the Air Pollution Control Association, held in Dallas, Texas, on June 19-24, published by the Air Pollution Control Association, Pittsburgh, Penn.

Lave, L.B., 1991, testimony D.P.U. 91-131 before the Commonwealth of Massachusetts Department of Public Utilities (D.P.U.), Boston, Mass.

Lave, L.B., and E.P. Seskin, 1977, Air Pollution and Human Health, Resources for the Future, Washington, D.C., published by Johns Hopkins Press, Baltimore, Md.

Liu, B., and E.S. Yu, 1976, Physical and Economic Damage Functions for Air Pollutants by Receptor, report prepared for U.S. Environmental Protection Agency, Corvallis, Ore.

Moore and W.K. Viscusi, 1988a, "The Quality of Adjusted Value of Life," Economic Enquiry 26(369), as cited in Ottinger et al. (1990). 
Moore and W.K. Viscusi, 1988b, "Doubling the Estimated Value of Life: The Implications of New Occupational Fatality Data," Journal of Policy Analysis and Management 7, as cited in Ottinger et al. (1990).

Morris, S., et al., 1979, "Coal Conversion Technologies: Some Health Environmental Effects," Science 206:654-662.

Olson, C., 1981, "An Analysis of Wage Differentials Received by Workers on Dangerous Jobs," The Journal of Human Resources 16(2).

Ottinger, R.L., et al., 1990, Environmental Costs of Electricity, D.R. Wolcott (editor), prepared by Pace University Center for Environmental Legal Studies for New York State Engineering Research and Development Authority and U.S. Department of Energy, published by Oceana Publications, New York, N.Y.

Plueksawan, W., 1991, "Coal Use in the Electricity Sector of Thailand," presented at Coal and the Environment: Asia 2010 Conference, sponsored by the East-West Center, Energy Program, and the U.S. Department of Energy, Office of Fossil Energy, held in Honolulu, Hawaii, on July 11-12.

Schulze, W.D., et al., 1983, "Economic Valuation of the Risks and Impacts of Energy Development," in Health Risks of Energy Technologies, C.C. Travis and E.L. Etnier (editors), selected symposia series, American Association for the Advancement of Science, Washington, D.C., Westview Press, Inc., Boulder, Colo., pp. 229-278.

Shuman, M., and R. Cavanagh, 1982, A Model Conservation and Electric Power Plan for the Pacific Northwest, App. A., Northwest Conservation Act Coalition, Seattle, Wash., Nov.

Small, K.A., 1977, "Estimating Air Pollution Costs of Transport Modes," Journal of Economics 11(2):109-132, May.

Smith, V.K., 1976, "The Measurement of Mortality and Air Pollution Relationships," Environment and Planning 8:149-162.

Szpunar, C.B., et al., 1980, The Fate of Trace Elements in Coal Combustion, report COR.24KW.80, Exxon Research and Engineering, Baytown, Texas, Dec.

Szpunar, C.B., and J.L. Gillette, 1990, Comparative Analyses for Selected Clean Coal Technologies in the International Marketplace, report ANL/EAIS/TM-39, Argonne National Laboratory, Argonne, Ill., July.

Thaler, R., and S. Rosen, 1976, "The Value of Saving a Life: Evidence from the Labor Market," in Household Production and Consumption, N. Terkeckyj (editor), Columbia Press, New York, N.Y. 
Tsai, J.-H., and F.-T. Jenq, 1988, "Representativeness of Ambient Air Quality Monitoring Station in Urban Area," in proceedings of the 81st annual meeting of the Air Pollution Control Association, held in Dallas, Texas, on June 19-24, published by the Air Pollution Control Association, Pittsburgh, Penn.

Tsai, J.-H., et al., 1991, "Spatial Variation of Carbon Monoxide Concentration around Air Quality Monitoring Stations in Taiwan," in proceedings of the International Conference on Environmental Pollution, held in Lisbon, Portugal, pp. 140-146.

Thibodeau, L.A., et al., 1980, "Air Pollution and Human Health: A Review and Reanalysis," Environmental Health Perspectives 34:165-181, Feb.

Viren, J.R., 1978, Cross-Sectional Estimates of Mortality due to Fossil Fuel Pollutants: A Case for Spurious Association, report prepared for U.S. Department of Energy, Washington, D.C.

Viscusi, W.K., 1989, "Toward a Diminished Role for Tort Liability: Social Insurance, Government Regulation, and Contemporary Risks to Health and Safety," Yale Journal on Regulation 6(1), winter.

Viscusi, W.K., 1983, Risk by Choice: Regulating Health and Safety in the Work place, as cited in Ottinger et al. (1990).

Viscusi, W.K., 1979, Employment Hazards: An Investigation of Market Performance, as cited in Ottinger et al. (1990).

Wadell, T.E., 1974, The Economic Damages of Air Pollution, U.S. Environmental Protection Agency, Office of Water Resources Research, Washington, D.C., May.

Wiel, S., 1991, "The New Environmental Accounting: A Status Report," Electricity Journal 4(9):46-54, Nov.

WHO and UNEP, 1984, Urban Air Pollution: 1973-1980, World Health Organization, Geneva, Switzerland, and United Nations Environment Programme, New York, N.Y.

WRI and IIED, 1988, World Resources 1988-1989: An Assessment of the Resource Base that Supports the Global Economy, World Resources Institute and International Institute for Environment and Development in collaboration with the United Nations Environment Programme, Basic Books, Inc., New York, N.Y. 


\section{BIBLIOGRAPHY}

Johnson, R.L., and G.V. Johnson (editors), 1990, Economic Valuation of Natural Resources: Issues, Theory, and Applications, Social Behavior and Natural Resources Series, Westview Press, San Francisco, Calif.

Szpunar, C.B., and J.L. Gillette, 1992, Environmental Externalities: An ASEAN Application to Coal-Based Power Generation - Extract, prepared by Argonne National Laboratory, Argonne, Ill., for the U.S. Agency for International Development, Office of Energy and Infrastructure, June. 

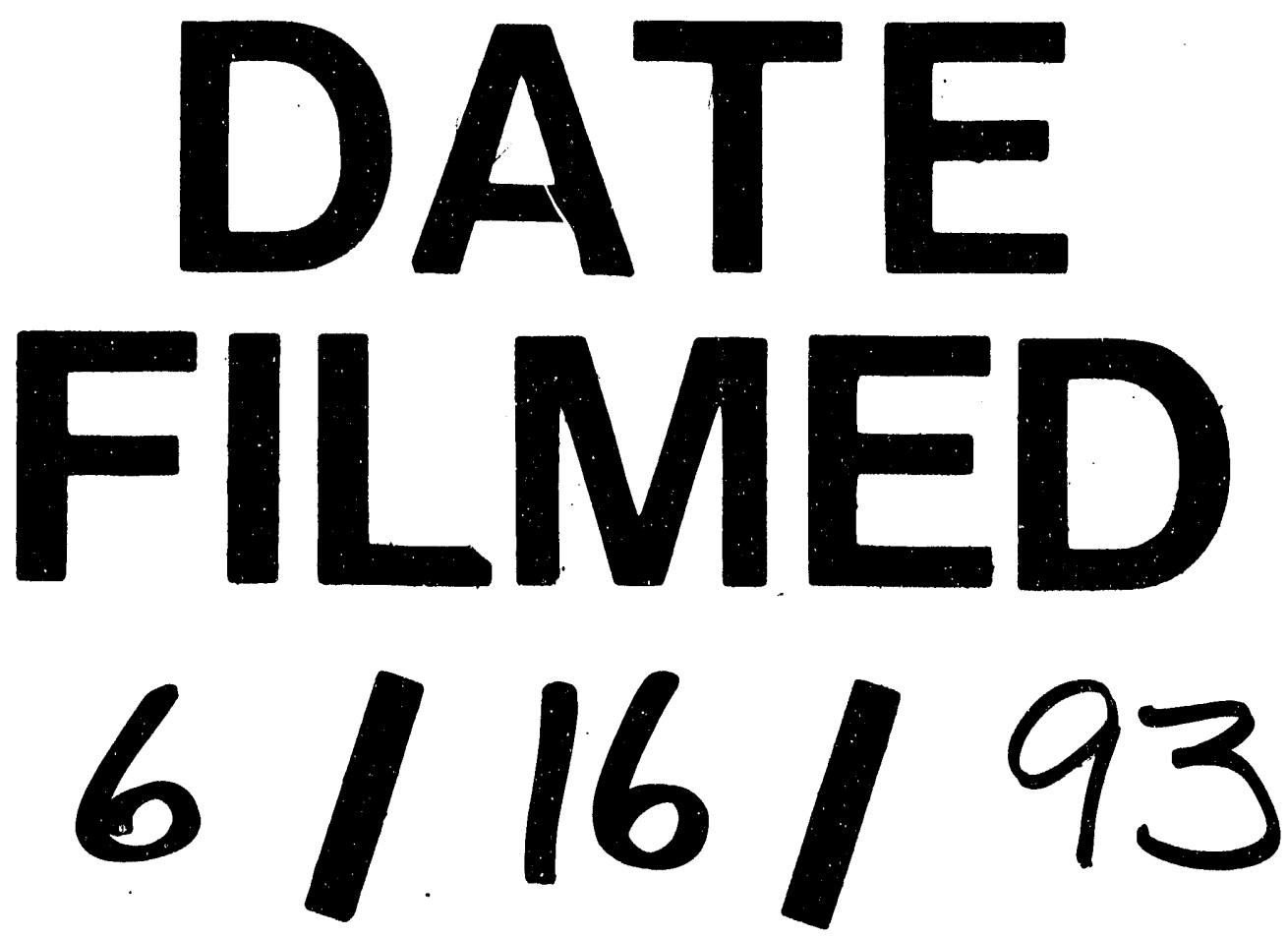
